Protist

November 2020, Volume 171, Issue 5, Pages 125759 (26p.)

https://doi.org/10.1016/i.protis.2020.125759

https://archimer.ifremer.fr/doc/00646/75802/

\title{
Taxonomy and Molecular Phylogenetics of Ensiculiferaceae, fam. nov. (Peridiniales, Dinophyceae), with Consideration of their Life-history
}

\author{
Li Zhun ${ }^{1}$, Mertens Kenneth 2, Gottschling Marc ${ }^{3}$, Gu Haifeng ${ }^{4}$, Söhner Sylvia ${ }^{3}$, Price Andrea M. 5, 6 , \\ Marret Fabienne ${ }^{7}$, Pospelova Vera ${ }^{8,9}$, Smith Kirsty F. ${ }^{10}$, Carbonell-Moore Consuelo ${ }^{11}$, \\ Nezan Elisabeth ${ }^{2,12}$, Bilien Gwenael ${ }^{2}$, Shin Hyeon Ho ${ }^{13,{ }^{*}}$
}

\begin{abstract}
1 Biological Resource Center, Korea Research Institute of Bioscience and Biotechnology, 181 Ipsingil, Jeongeup 56212, Republic of Korea

2 Ifremer, LER BO, Station de Biologie Marine, Place de la Croix, BP40537, F-29185 Concarneau Cedex, France

${ }^{3}$ Department Biologie, Systematische Botanik und Mykologie, GeoBio-Center, Ludwig-Maximilians-

Universität München, Menzinger Str. 67, D-80638 München, Germany

4 Third Institute of Oceanography, Ministry of Natural Resources, Xiamen 361005, China

${ }^{5}$ Dr. Moses Strauss Department of Marine Geosciences, Leon H. Charney School of Marine Sciences, University of Haifa, 199 Abba Khoushy Ave., Haifa 3498838, Israel

${ }^{6}$ Louisiana Universities Marine Consortium, 8124 Highway 56, Chauvin, Louisiana 70344, USA

7 School of Environmental Sciences, University of Liverpool, Liverpool, L69 7ZT, UK

8 Department of Earth and Environmental Sciences, University of Minnesota, College of Science and Engineering, 116 Church Street SE, Minneapolis, MN 55455, USA

${ }^{9}$ School of Earth and Ocean Sciences, University of Victoria, OEASB A405, Victoria, British Columbia, V8P 5C2, Canada

10 Coastal and Freshwater Group, Cawthron Institute, Nelson 7042, New Zealand

11 Oregon State University, Department of Botany and Plant Pathology, College of Agricultural

Sciences, 2082 Cordley Hall, Corvallis, OR 97331-2902, USA

12 National Museum of Natural History, DGD-REVE, Station de Biologie Marine de Concarneau, Place de la Croix, 29900 Concarneau, France

${ }^{13}$ Library of Marine Samples, Korea Institute of Ocean Science and Technology, Geoje 53201, Republic of Korea
\end{abstract}

* Corresponding author : Hyeon Ho Shin, email address : shh961121@kiost.ac.kr

\begin{abstract}
:
In the current circumscription, the Thoracosphaeraceae comprise all dinophytes exhibiting calcified coccoid cells produced during their life-history. Species hitherto assigned to Ensiculifera and Pentapharsodinium are mostly based on the monadoid stage of life-history, while the link to the coccoid stage (occasionally treated taxonomically distinct) is not always resolved. We investigated the different life-history stages and DNA sequence data of Ensiculifera mexicana and other species occurring in samples collected from all over the world. Based on concatenated ribosomal RNA gene sequences Ensiculiferaceae represented a distinct peridinalean branch, which showed a distant relationship to other calcareous dinophytes. Both molecular and morphological data (particularly of the coccoid stage)
\end{abstract}


revealed the presence of three distinct clades within Ensiculiferaceae, which may include other dinophytes exhibiting a parasitic life-history stage. At a higher taxonomic level, Ensiculiferaceae showed relationships to parasites and endosymbionts (i.e., Blastodinium and Zooxanthella) as well as to dinophytes harbouring diatoms instead of chloroplasts. These unexpected phylogenetic relationships are corroborated by the presence of five cingular plates in all such taxa, which differs from the six cingular plates of most other Thoracosphaeraceae. We herein describe Ensiculiferaceae, emend the descriptions of Ensiculifera and Pentapharsodinium, erect Matsuokaea and provide several new combinations at the species level.

Keywords : Dinoflagellate, molecular phylogenetics, parasite, plate overlap, rRNA, thecal plate 


\section{Introduction}

The life-history of the predominantly unicellular dinophytes is complex and frequently comprises at least two morphologically and ecologically distinct stages: a motile, monadoid stage and an immotile, coccoid stage that is commonly deposited in the sediment (here, the terms for the various life stages refer purely to morphology, whilst the terms 'vegetative cell' and 'cyst' are connoted functionally and/or ecologically). Coccoid cells may have diverse functions (Dale 1983; Fensome et al. 1993), including dormancy to survive unfavourable ecological (e.g., seasonal) conditions (hence why they are colloquially termed 'resting cysts'). In addition to monadoid cells, some dinophytes exhibit parasitic stages, which were first recognised a century ago (Chatton 1920; Chatton and Grassé 1952; Cachon and Cachon 1987; Coats 1999). The hosts of parasitic dinophytes are taxonomically broad and include fish, copepods, flatworms and corals, as well as unicellular organisms such as ciliates, radiolarians and other dinophytes. Molecular sequence data have shown that parasitic dinophytes are a polyphyletic assemblage, nesting within subordinate groups of dinophytes such as the Gymnodiniales (Gómez et al. 2009), Peridiniales (Litaker et al. 1999; Coats et al. 2010) and $†$ Suessiales (considered to include extant taxa such as Polarella Montresor, Procaccini \& Stoecker; Levy et al. 2007). However, parasitic dinophytes remain poorly studied, and precise information on host specificity, infective process, life-history, ploidy level and phylogenetic relationship is available for only a limited number of species. 
The group of calcareous dinophytes is difficult to circumscribe. They are characterised by the production of calcareous coccoid cells during their life-history (Elbrächter et al. 2008; Gottschling and Söhner 2013). Because of their high potential to fossilise, they are well documented in the fossil record (Bolli 1974; Deflandre 1949; Hildebrand-Habel and Streng 2003; Keupp 1981, 1991; Streng et al. 2004; Wanner 1940; Zonneveld et al. 1999). The trait of calcification is unique among extant alveolates and was considered apomorphic for calcareous dinophytes (Elbrächter et al. 2008; Gottschling et al. 2005; Janofske 1992; Wall and Dale 1968). It was surprising to discover from subsequent molecular studies that many calcareous dinophytes have close relatives, for which the potential for calcification is not known (Gottschling et al. 2005, 2012; Gottschling and Söhner 2013; Luo et al. 2016). Calcareous dinophytes, together with their non-calcareous relatives, have been unified within the Thoracosphaeraceae (Elbrächter et al. 2008; Gottschling and Söhner 2013), which is subdivided into three major groups: 1) the E/Pe-clade consisting of Ensiculifera Balech and Pentapharsodinium Indel. \& A.R.Loebl.; 2) the T/Pf-clade comprising Pfiesteria Steid. \& J.M.Burkh., Thoracosphaera Kamptner and their relatives; and 3) the Scrippsiella Balech sensu lato (s.l.) clade (Gottschling et al. 2005, 2012; Gu et al. 2013a). The latter two clades are closely related as inferred from molecular phylogenies, but the phylogenetic placement of the E/Pe clade within the Peridiniales still remains unclear. A close relationship to a clade composed of endosymbionts (i.e., Zooxanthella K.Brandt), parasites (i.e., Blastodinium Chatton) and the Kryptoperidiniaceae harbouring diatom endosymbionts, rather than to the other Thoracosphaeraceae, appears more likely (Gottschling and McLean 2013; Gottschling et al. 2017; Kretschmann et al. 2018a).

The taxonomy and nomenclature of Ensiculifera and Pentapharsodinium are complex. The generic name Ensiculifera was established by Balech (1967), with Ensiculifera mexicana Balech as type and delimited from Scrippsiella by the presence of five (versus six) cingular plates and an internal spine ('ensiculum') attached to the first cingular (c1) plate. Later, Ensiculifera loeblichii El.R.Cox \& H.J.Arn. was described; it also has five cingular plates but lacks a long spine on the c1 plate (Cox and Arnott 1971), broadening the original taxonomic concept of Ensiculifera. It is notable that the presence of a cingular spine 
is not restricted to Ensiculifera among calcareous dinophytes. A similar structure, though attached to the anterior sulcal (Sa) not the c1 plate, is described for Scrippsiella trochoidea var. aciculifera Montresor (Montresor et al. 2003) from the Scrippsiella s.l. clade and Pentapharsodinium dalei var. aciculiferum H.Gu (Gu et al. 2013b) and Pentapharsodinium jinhaense Zhun Li, M.S.Han \& H.H.Shin (Li et al. 2015b) from the E/Pe-clade. Thus, the presence or absence of spines is not unequivocally diagnostic between Ensiculifera, Pentapharsodinium and Scrippsiella.

Indelicato and Loeblich III (1986) considered Ensiculifera not validly published, because a Latin description or diagnosis was not provided by Balech (1967). Therefore, they rejected the name Ensiculifera and erected the new generic name Pentapharsodinium, with Pentapharsodinium dalei Indel. \& A.R.Loebl. as type. They also incorporated E. loeblichii into Pentapharsodinium, while E. mexicana was transferred to Scrippsiella. However, Enrique Balech (1912-2007) consistently considered dinophytes under the International Code of Zoological Nomenclature (ICZN; Elbrächter et al. 2008), in which a Latin description is not a condition for the equivalent of valid publication. If all requirements of another relevant code are satisfied, then Article 45.1 of the International Code of Nomenclature for algae, fungi, and plants (ICN; Turland et al. 2017) specifies that such names are valid. A similar case has been made for Scrippsiella (Andersen 2018 and references therein) and can also be made for Fragilidium Balech.

Knowledge of the link between the different life-history stages of calcareous dinophytes has increased in recent decades (e.g., Dale 1983; Gu et al. 2013a, 2013c; Lewis 1991; Li et al. 2015a, 2015b; Matsuoka et al. 1990; Zinßmeister et al. 2012), and both monadoid and coccoid cells have been recognised in species of Ensiculifera and Pentapharsodinium. Identification of coccoid cells is generally based on shape, size, colour, operculum and archaeopyle as well as constitution of the wall (not necessarily a variation on, or homologue of, the cellulosic cell wall: Elbrächter et al. 2008) regarding ornamentation, ultrastructure (orientation of the calcitic crystals' crystallographic c-axis) and geochemical composition (Dale 1983; Elbrächter et al. 2008; Fensome et al 1993; Janofske 1996; Karwath 2000; Keupp 1991; Kohring et al. 2005; Li et al. 2005a; Mertens et al. 2013; Streng et al. 2004). The existence of these two stages has led to the 
erection of separate neontological and palaeontological nomenclatures. As a result, the two heterotypic names Pentapharsodinium tyrrhenicum (Balech) Montresor, Zingone \& D.Marino ex Head and $\uparrow$ Calcicarpinum bivalvum G.Versteegh represent the same biological species (Montresor et al. 1993). Other species exhibiting two different stages are currently treated under a single name (e.g., P. dalei: Dale 1977; Ensiculifera carinata Matsuoka, S.Kobayashi \& Gains: Matsuoka et al. 1990; E. imariensis S.Kobayashi \& Matsuoka: Kobayashi and Matsuoka 1995) or have coccoid cells not being described until now (e.g., $E$. loeblichii, E. mexicana).

Eight extant species and a variety are currently classified in the E/Pe-clade, though not all taxa are yet characterised by molecular sequence data (e.g., E. carinata, E. mexicana). The lack of information regarding taxonomic availability and typification of scientific names, the degree of morphological variation (particularly regarding the coccoid cells) and paucity of DNA sequence data for many critical species hinders the development of a clear and integrative taxonomy within the E/Pe-clade. In the present study, we investigate the type species of Ensiculifera, namely E. mexicana, on the basis of morphological and molecular data. This taxonomic clarification allows for the differentiation between Ensiculifera and Pentapharsodinium, and the erection of Matsuokaea. The three lineages can be primarily distinguished by the morphology of their coccoid cells. In molecular phylogenetics, we include a sequence obtained from a ctenophoran parasite that nests within the E/Pe-clade. The parasite attaches to the ectoderm or is embedded in the mesoglea of the ctenophore, where it causes localised collapse of the mesoglea, particularly in regions near the aboral pole (Smith 2011; Smith et al. 2007). Overall, the aim of this study was a better understanding of calcareous dinophytes, in particular their life-history and morphology of coccoid cells, and an adjusted taxonomy.

\section{Results}




\section{Morphology}

\section{Ensiculifera mexicana}

The monadoid cells of strain LMBE-TY1 from Korea are solitary, ovoid and yellow in colour (Fig. 1AF). The cells are 30.7-49.6 $\mu \mathrm{m}$ (average: $41.7 \mu \mathrm{m}, \mathrm{n}=50$ ) in length and 25.5-38.9 $\mu \mathrm{m}$ (average: $34.2 \mu \mathrm{m}$, $\mathrm{n}=50$ ) in width. The length of the epitheca is generally the same as the hypotheca (Fig. 1A, C). The hypotheca is rounded and lacks horns or projections (Fig. 1A-F). The cingulum is subequatorial and descending, its ends displaced by one-half cingulum width (Fig. 1A, E). Cells contain reticular chloroplasts and a pyrenoid (Fig. 1B, G). The nucleus is elongated and located centrally in the posterior part of the cell (Fig. 1H-I).

Motile cells display a plate tabulation formula of Po, X, 4', 3a, 7", 5c, 5S, 5"', 2"'" (Fig. 2A-I). Many pores and small granules or bumps are randomly distributed on the thecal surface (Fig. 2A-I). The epitheca is conical, with plate Po surrounded by a small collar located centrally at the apex (Fig. 2E) and having a round apical pore (Fig. 2E). The first apical plate $\left(1^{\prime}\right)$ is longer than wide and contacts plates $\mathrm{X}, 2^{\prime}, 4^{\prime}, 1^{\prime \prime}$ and 7' (Fig. 2A, D-E). Plates 2' and 4' are hexagonal in shape and larger than plate 3' (Fig. 2E). Plate 3' is hexagonal in shape and contacts plates Po, $2^{\prime}$ and $4^{\prime}$ as well as the three anterior intercalary plates (Fig. 2C, E). Plate 2a is a symmetrical hexagon (Fig. 2) and is larger than plates 1a and 3a. Seven precingular plates are arranged symmetrically. Plates 1" and 4" are rectangular in shape (Fig. 2A-B, D-E). Plates 2", 3", 5" and $6 "$ are pentagonal in shape (Fig. 2B-E). Plate 4" is smaller than plates $3 "$ and 5" (Fig. 2C, E). On the hypotheca, the postcingular plates are arranged symmetrically (Fig. 2G). Plate $3^{\prime \prime \prime}$ is the smallest postcingular plate and pentagonal in shape (Fig. 2C, G); the other postcingular plates are trapezoidal in shape (Fig. 2G). The antapical plates $1^{\prime \prime \prime \prime}$ and 2'"' are pentagonal in shape, dissimilar in size, larger than the five postcingular plates and in contact with the posterior sulcal plate (Fig. 2G).

The cingulum is slightly excavated and is formed by five plates (Fig. 2A-F). The c1 plate of the cingular series is the smallest and encroaches on the left-hand side of the anterior sulcal area (Fig. 2F, HI). A spine is attached to the c1 plate and is covered by plate 1' (Fig. 2F, H-I). Plates c3 and c4 are larger 
than the plates c2 and c5 (Fig. 2F). The sulcus is narrow and consists of five plates (Fig. 2A, G-I). The anterior sulcal plate (Sa) is small and located between plates 1" and 7" (Fig. 2H). The left sulcal (Ss) and right sulcal (Sd) plates are narrow, larger than plate Sa and connect to plates c1 and Sa, respectively (Fig. $2 \mathrm{H}-\mathrm{I})$. The median sulcal plate $(\mathrm{Sm})$ is very small, almost completely covered by the wing attached to the posterior sulcal (Sp) plate (Fig. 2A, G) and is seen only in internal views (Fig. 2I). The Sp plate is short, pentagonal, extends into the hypotheca without reaching the antapex and does not contact plate c1 (Fig. 2A, $\mathrm{G})$.

Coccoid cells are brown, with an internal, prominent, red body (Fig. 3A-B, D-E). Cell size ranges from 57.5 to $68.4 \mu \mathrm{m}$ (average: $62.5 \mu \mathrm{m}, \mathrm{n}=6$ ) in length and 48.5 to $58.7 \mu \mathrm{m}$ (average: $56.2 \mu \mathrm{m}, \mathrm{n}=6$ ) in width. The coccoid cell is roughly pentagonal in apical view and subrectangular in lateral view (Fig. 3AC). The calcareous wall is thin between the thick crests (Fig. 3A). The strong equatorial ridges correspond to cingular sutural structures. The endocoel is subspherical (or slightly ellipsoidal), 42.9 to $47.2 \mu \mathrm{m}$ in diameter (average: $44.6 \mu \mathrm{m}, \mathrm{n}=6$ ) (Fig. 3D). The archaeopyle is subcircular (Fig. 3F) and is located at the centre of the apical face (Fig. 3F-I). The operculum may remain attached after excystment (Fig. 3G-I). The operculum is subcircular $(22.5 \mu \mathrm{m}$ in diameter, $\mathrm{n}=2)$ with a smooth edge (Fig. 3G-I). The coccoid cells were not observed in the cultivated strain.

\section{Ensiculifera carinata}

The monadoid cells of strain D3 from New Zealand are 20.5-51.2 $\mu \mathrm{m}$ long (average: $42.3 \mu \mathrm{m}, \mathrm{n}=20$ ) and 16.8-36.5 $\mu \mathrm{m}$ wide (average: $30.3 \mu \mathrm{m}, \mathrm{n}=20$ ). The epitheca is convex-conical and the hypotheca is hemispherical (Supplementary Material Fig. S1). The cells display a plate formula of Po, X, 4', 3a, 7", 5c, 5S, 5"', 2'"' (Supplementary Material Fig. S1). A spine approximately $13 \mu \mathrm{m}$ long is attached to the c1 plate and is hidden behind plate $1^{\prime}$. The thecal plates are covered with many pores and small granules or bumps (Supplementary Material Fig. S1). A single hollow spine is observed at the triple junction of plates Sp, $1^{\prime \prime \prime \prime}$ and 2"'"' (Supplementary Material Fig. S1).

Coccoid cells are spherical and brown (Fig. 4A). The diameter of the cell body ranges from 41.6 to 
$58.5 \mu \mathrm{m}$ (average: $50.3 \mu \mathrm{m}, \mathrm{n}=10$ ). The calcareous wall is ridged and covered by numerous needle-shaped calcareous crystals (Fig. 4B-D). The cingular and sulcal equivalents are observed on the calcareous wall. When the outer calcareous layer is dissolved at a low $\mathrm{pH}$ using a $\mathrm{CO}_{2}$ incubator (Fig. 4E-F), a prominent reddish pigment body is always visible (Fig. 4E). The naked coccoid cell has a smooth organic wall that is distinctly visible (Fig. 4F). The archaeopyle is intercalary and theropylic (Fig. 4F). Coccoid cells were not observed in the cultivated strain.

\section{Pentapharsodinium imariense}

The monadoid cells of strain OP2E4 from New Zealand are ovoid, 18.1-21.3 $\mu \mathrm{m}$ long (average: $20.2 \mu \mathrm{m}$, $\mathrm{n}=20$ ) and $13.2-17.5 \mu \mathrm{m}$ wide (average: $14.5 \mu \mathrm{m}, \mathrm{n}=20$ ). The epitheca is conical, whereas the hypotheca is hemispherical (Fig. 5). The plate formula is Po, X, 4', 3a, 7", 5c, 5S, 5"', 2'"' (Fig. 5 A-F). The thecal plates (except plates Po and X) are covered with numerous trichocyst pores, where each pore is surrounded by one or two concentric circles. The pore plate is surrounded by a small collar (Fig. 5A, C). Three intercalary plates of similar size are present on the dorsal part of the epitheca (Fig. 5B-C). The cingulum is deep and descending by one-half of the cingulum width (Fig. 5A, D-E). The cingulum consists of five plates. A long spine $(>10 \mu \mathrm{m})$ is attached to plate $\mathrm{c} 1$ and is covered by plate $1^{\prime}$. Plate $3^{\prime \prime \prime}$ is pentagonal in shape and is the smallest of the postcingular plates. The two antapical plates $11^{\prime \prime \prime \prime}$ and $2^{\prime \prime \prime \prime}$ are nearly the same size and are symmetrical (Fig. 5A, D, F). The sulcal series comprises five plates: Sa, Sd, Sm, Ss and Sp (Fig. 5D-E). The Sp plate is short and does not contact c1 (Fig. 5A, E).

The coccoid cells are spherical, transparent to greenish-brown and 19.6-23.5 $\mu \mathrm{m}$ (average: $20.8 \mu \mathrm{m}$, $\mathrm{n}=10$ ) in diameter (Fig. 6A-D). Live coccoid cells contain several greenish granules. The cell wall is thick and bears numerous processes (average: $4.3 \mu \mathrm{m}$ long, n=10; Fig. 6A-F). The processes bear small bumps, and the distal end of these processes range from simple to branched at the apex, with or without capitate tips (Fig. 6 E-H). No archaeopyle was observed. The coccoid cells were also observed in the cultivated strain. 


\section{Matsuokaea loeblichii}

The monadoid cells of strain LMBE-JH2 from Korea are solitary, pyriform and yellow-green (Fig. 7A-D). The cells are 18.6-31.3 $\mu \mathrm{m}$ (average: $24.4 \mu \mathrm{m}, \mathrm{n}=50$ ) in length and 14.6-22.5 $\mu \mathrm{m}$ (average: $18.2 \mu \mathrm{m}, \mathrm{n}=50$ ) in width. The length of the epitheca is generally similar to that of the hypotheca (Fig. 7A). The cingulum is subequatorial and descending, displaced by one half the cingulum width (Fig. 7A-C). A rod-shaped eyespot is located on the right side of the sulcus (Fig. 7A, B). The elliptical nucleus in the hypotheca is prominent (Fig. 7D, E). The cells contain ribbon-like chloroplasts (Fig. 7F).

The cells have a plate formula of Po, X, 4', 3a, 7", 5c, 5S, 5"', 2'"' (Fig. 8A-J). Many pores and small bumps are randomly distributed on the thecal surface. Plate Po is surrounded by a small collar and together they form a conspicuous horn (Fig. 8A-C). The first apical plate (1') contacts seven plates: X, 2', 4', 1', 7", Sa and c1 (Fig. 8A, G, J). Three intercalary plates (1a, 2a and 3a) are of similar size and are present on the dorsal part of the epitheca (Fig. 8F). The precingular plates are symmetrically distributed. Plates 1" and 7" are larger than the others. Plates $1 ", 3^{\prime \prime}$ and $7 "$ are trapezoidal, and the other precingular plates are pentagonal. The hypotheca is composed of five postcingular plates and two antapical plates being symmetrically arranged. Plates $1{ }^{\prime \prime \prime}, 2^{\prime \prime \prime}, 3^{\prime \prime \prime}$ and 4 "' are tetragonal, nearly equal in size and longer than they are wide, whereas plate $3^{\prime \prime \prime}$ is small and pentagonal in shape (Fig. 8D, H). The two antapical plates $1^{\prime \prime \prime \prime}$ and $2^{\prime \prime \prime \prime}$ are similar in size and have pentagonal shapes (Fig. $8 \mathrm{H}$ ). The cingulum is regularly descending but not deeply excavated and is formed by five plates (Fig. 8A, B, I). Plate c1 bears no spine (Fig. 8I). The sulcus is narrow with inconspicuous lists and does not contact the antapex (Fig. 8A, B). The sulcus consists of four major plates: plate Sa is small, located between plates 1' and 7"; plates Ss and Sd are short (Fig. 8J); and plate $\mathrm{Sp}$ is the largest sulcal plate and does not contact plate c1 (Fig. 8J).

The coccoid cells are spherical in shape, the wall is transparent, consisting of two layers, an outer thin layer and a thicker endospore layer below. Cell content is yellow-green with a prominent red body (Fig. $7 \mathrm{G}, \mathrm{H}$ ). The diameter of coccoid cells ranges from 19.5 to $25.2 \mu \mathrm{m}$ (average: $21.6 \mu \mathrm{m}, \mathrm{n}=10$ ). The organic wall is thick and smooth without any distinguishing features on the surface (Fig. 7I). The coccoid cells were 
also observed in the cultivated strain.

\section{Plate Overlap}

The overlap patterns of E. mexicana, M. loeblichii and P. imariense were determined from differential marginal growth in the sutures of two adjacent plates (Fig. 9). These three species have an identical plate overlap pattern. Plate overlap in epithecal, cingular and hypothecal plate series follow two general gradients: from dorsal to ventral and from the cingulum to the two poles. The fourth precingular $\left(4^{\prime \prime}\right)$, the third postcingular (3"') and the third cingular (3c) plates were identified as keystone plates, which overlap all their adjacent plates. On the epitheca, the middle intercalary plate 2a overlaps the other intercalary plates. On the hypotheca, the second antapical plate $2^{\prime \prime \prime \prime}$ overlaps plate $1^{\prime \prime \prime \prime}$. Among the sulcal plates, plate Sp is overlapped by all hypothecal plates. Plates $\mathrm{Sd}$ and Ss are overlapped by 5 "' and 1"', respectively.

\section{Molecular Phylogeny}

The SSU + ITS + LSU alignment was $1,726+934+1,112$ bp long and comprised $302+557+427$ parsimony informative sites as well as 1,901 distinct RAxML alignment patterns. In the phylogenetic tree (Fig. 10), peridinialean dinophytes segregated into Blastodinium Chatton (100LBS, 1.00BPP), Ensiculiferaceae (97LBS, 1.00BPP), Kryptoperidiniaceae (99LBS, 1.00BPP), Peridiniaceae (100LBS, 1.00BPP), Peridiniopsidaceae (97LBS, 1.00BPP), Thoracosphaeraceae (98LBS, 1.00BPP) and Zooxanthella (single accession). Calcareous dinophytes were distributed over three lineages: Ensiculiferaceae, Scrippsiella s.l. (84LBS, 1.00BPP) and the T/Pf-clade (76LBS, 0.97BPP), but did not constitute a monophyletic group. Rather, Scrippsiella s.l. and the T/Pf-clade were closer related (76LBS, 0.97BPP), but Ensiculiferaceae showed a closer relationship to Blastodinium, Kryptoperidiniaceae and Zooxanthella, albeit with low support (53LBS).

The ITS alignment was 1,114 bp long and comprised 579 parsimony informative sites as well as 846 distinct RAxML alignment patterns. Bayesian and ML analyses generated similar trees (Fig. 11), and 
Ensiculiferaceae constituted a less well-supported group (60LBS, 1.00BPP). They segregated into the three major clades: Ensiculifera (50LBS, 0.92BPP), Matsuokaea (95LBS, 1.00BPP) and Pentapharsodinium (85LBS, 1.00BPP). Ensiculifera and Pentapharsodinium were closer related (0.91BPP) than any of them to Matsuokaea. Ensiculifera includes four previously described species: the type E. mexicana (90LBS, 1.00BPP), E. carinata (94LBS, 1.00BPP), E. jinhaensis (single accession) and E. tyrrhenica (99LBS, 1.00BPP). Additionally, Ensiculifera included the sequence from a parasite that was almost identical to a sequence from an unidentified calcified coccoid cell (Supplementary Material Fig. S2; 100LBS, 1.00BPP). Pentapharsodinium segregated into four clades, including the type P. dalei (98LBS, 1.00BPP), P. dalei var. aciculiferum (100LBS, 1.00BPP), P. imariense, comb. nov (100LBS, 1.00BPP), and an undescribed species (strain SSND22 from China). Divergence values from ITS sequences of Ensiculiferaceae are provided in Table S3.

\section{Discussion}

\section{Correlations Between Molecular Phylogenetics and Morphological Traits}

The phylogenetic analyses presented here concur with previous studies (Gottschling et al. 2005, 2012; Gu et al. 2013a; Gottschling and Söhner 2013): the E/Pe-clade is reliably monophyletic and segregates into three lineages. Strikingly, the three lineages are characterised by differences in the coccoid cell's wall composition and/or ornamentation (Fig. 11): Ensiculifera is characterised by calcareous coccoid cells of various shapes with an operculum corresponding to a single plate equivalent (Matsuoka et al. 1990; Montresor et al. 1993; Gottschling et al. 2005; Li et al. 2015b); Pentapharsodinium comprises organicwalled coccoid cells, centrifugal processes of similar length and termination and an apical split as an archaeopyle (Gu et al. 2013b; Kobayashi and Matsuoka 1995); Matsuokaea exhibits smooth, organicwalled coccoid cells (archaeopyle unknown). In the phylogenetic tree based on ITS sequences, an undetermined species of Pentapharsodinium (EU728696; strain SSND22 from China) produces a coccoid cell characterised by short organic-walled processes on the surface. As the coccoid cell is morphologically 
similar to those of $P$. dalei and P. imariense (Gu and Wang 2007), this unnamed species can be assigned to

\section{Pentapharsodinium.}

Members of the Ensiculiferaceae are morphologically distinct from other calcareous dinophytes. Most notably, Ensiculifera, Matsuokaea and Pentapharsodinium have five cingular plates, which distinguishes them from most other members of the Thoracosphaeraceae having six such plates (incl. Scrippsiella s.l. and Thoracosphaera: Dale 1977; Fensome et al. 1993). This is also highlighted by recent molecular phylogenies, which show a closer relationship between Ensiculiferaceae and an ecologically heterogeneous assemblage comprising of Blastodinium, Kryptoperidiniaceae and Zooxanthella (Gottschling and McLean 2013; Gottschling et al. 2017; Kretschmann et al. 2018a) rather than the other Thoracosphaeraceae. Strikingly, these taxa also have five cingular plates (Probert et al. 2014; Kretschmann et al. 2018a; Skovgaard and Salomonsen 2009), supporting a close relationship with the Ensiculiferaceae. The Peridiniaceae (in a strict sense: Gottschling et al. 2017) also have three intercalary and five cingular plates, but can be distinguished from the Ensiculiferaceae based on habitat preference (freshwater versus marine). Furthermore, the position of the Ensiculiferaceae is distinct from Peridiniaceae and other peridinialean dinophytes in molecular phylogenies (Fig. 11). Thus, we propose the erection of Ensiculiferaceae within the Peridiniales for the species of the E/Pe-clade (see below).

Usually, the thecal tabulation, with its highly diverse arrangements and plate shapes, is considered diagnostic of groups of armoured dinophytes at different taxonomic levels (Fensome et al. 1993; Hoppenrath 2017; Taylor 1980). However, thecate cells of taxa within the Ensiculiferaceae have indistinguishable tabulation patterns, although the ornamentation can be different. Thus, the morphology of the coccoid cells is used to differentiate taxa within the Ensiculiferaceae in addition to diagnostic DNA sequences. A greater diversification of the coccoid cells compared to the thecate cells is common in other dinophyte lineages such as the Gonyaulacaceae, Protoperidiniaceae and Thoracosphaeraceae (Elbrächter et al. 2008; Ellegaard et al. 2003; Li et al. 2015a, 2015b; Matsuoka and Head 2013; Shin et al. 2014; Wall and Dale 1968). The morphological features of coccoid cells assigned to Ensiculiferaceae (Dale 1977; Gu et al. 
2013b; Kobayashi and Matsuoka 1995; Li et al. 2015b; Matsuoka et al. 1990; Montresor et al. 1993) are summarised in Table 1. Anyhow, coccoid cell diversity and function(s) are still poorly understood.

The correlation between molecular phylogenetics and coccoid cell morphology is straightforward, but the presence and position of spines associated with cingular plates on the thecate cells are difficult to interpret. Three states can be distinguished within the E/Pe-clade: 'spine on the c1 plate' (in E. carinata, E. mexicana, P. imariense: Balech, 1967; Kobayashi and Matsuoka 1995; Matsuoka et al. 1990), 'spine on the Sa plate' (in E. jinhaensis, P. dalei var. aciculiferum: Gu et al. 2013b; Li et al. 2015b) and 'no spine' (in E. tyrrhenica, M. loeblichii, P. dalei: Cox and Arnott 1971; D'Onofrio et al. 1999). However, the groups with each of these states do not cluster together in the phylogenetic tree (Fig. 11), and the trait cannot be used to distinguish Ensiculifera from Pentapharsodinium. However, it may help to distinguish taxa of the Ensiculiferaceae at the species level.

As the presence of spines does not accord with the groupings in the phylogenetic tree, the question prompts as to whether observations of the exact position of the spines in the literature are correct and, if not, whether such spines may be homologues across Ensiculiferaceae. Further research is necessary to explain the confusion regarding presence and position of the spine associated with cingular plates. At least, the cingular spine described for S. trochoidea var. aciculifera Montresor (D'Onofrio et al. 1999) appears as an independent development as inferred from the phylogenetic trees of calcareous dinophytes (Gottschling et al. 2005; Gu et al. 2013b). In addition, E. carinata, E. jinhaensis, E.mexicana, E. tyrrhenica and M. loeblichii have many pores and bumps on the thecal surface, whereas the thecal surface of all species of Pentapharsodinium is smooth (Gu et al. 2013b; Kobayashi and Matsuoka 1995; Li et al. 2015b; Matsuoka et al. 1990; Montresor et al. 1993).

Plate overlap patterns are generally considered to be conserved at higher taxonomic levels (Netzel and Dürr 1984). This assumption is supported by the Ensiculiferaceae, which show a consistent plate overlap pattern (Fig. 9, Supplementary Material Fig. S3). The epithecal plate overlap patterns are the same as in most peridinioid dinophytes (e.g., Durinskia Carty \& El.R.Cox and Scrippsiella: Kretschmann et al. 2015, 
2018a), with the fourth precingular plate forming the keystone plate. This differs from gonyaulacoid dinophytes, in which the third precingular plate is identified as the keystone plate in Lingulodinium polyedra (F.Stein) J.D.Dodge and Pyrrhotriadinium sphaericum (G.Murray \& Whitting) Nakada (Fensome et al. 1993). For Ensiculiferaceae, plate $3 \mathrm{c}$ is identified as the keystone plate for the cingular series, which has been previously reported for Durinskia oculata (F.Stein) Hansen \& Flaim (Kretschmann et al. 2018a). In contrast, plate $4 \mathrm{c}$ is the keystone plate in many other peridinioid species including Heterocapsa steinii Tillmann, Gottschling, Hoppenrath, Kusber \& Elbr. (Tillmann et al. 2017), Parvodinium travinskii Kretschmann, Owsianny, Zerdoner \& Gottschling and Parvodinium mixtum Wołosz. ex Kretschmann, Owsianny, Zerdoner \& Gottschling (Kretschmann et al. 2018b) and Scrippsiella acuminata (Ehrenb.) Kretschmann, Zinssmeister, S.Soehner, Elbr., Kusber \& Gottschling (Kretschmann et al. 2015).

\section{Taxonomic Clarifications in Ensiculiferaceae}

Since its first description by Balech (1967), E. mexicana has been rarely reported in the scientific literature (Licea et al. 2004; Okolodkov and Gárate-Lizárraga 2006; Wall and Dale 1968; Wall et al. 1970). To the best of our knowledge, no studies or illustrations exist that could improve the initial description of this species. Unfortunately, Balech (1988) created confusion himself when he presented illustrations of $E$. mexicana with six cingular plates, contradicting his original description of five such plates. One of the most important results of this present study is to demonstrate that there is a species, namely E. mexicana, having the combination of five cingular plates and a distinct spine on the first cingular plate. The only differences between the specimens shown in our SEM images and those in the original drawings provided by Balech (1967) is that the second intercalary plate is narrower and the apical elongation of the anterior sulcal plate is absent. Nevertheless, the morphology of the monadoid cells is consistent with the protologue of $E$. mexicana (Balech 1967) to the extent that we are confident to have isolated the species for the first time after half a century. A comparison of E. mexicana with related species is compiled in Table 1.

Here, we report E. mexicana from the western Pacific and not from the western Atlantic where it was 
originally described, indicating a broader distribution of the species. To support the present work, we plan to provide the epitypification in future based on material from the Gulf of Mexico, the type locality of $E$. mexicana (Balech 1967). The importance of this approach has been discussed in various previous studies (Kretschmann et al. 2015, 2018a, b; Tillmann et al. 2017). Nevertheless, this work provides a taxonomic clarification of Ensiculifera at the generic level.

Molecular phylogenetics indicate that $P$. imariense is not closely related to Ensiculifera but to Pentapharsodinium and its type, P. dalei (Figs 10, 11). This is corroborated by morphological characteristics: the thecal surface has numerous trichocyst pores surrounded by concentric circles, and the organic-walled coccoid cell has capitate processes (Gu et al. 2013b; Indelicato and Loeblich III. 1986; Kobayashi and Matsuoka 1995). However, P. imariensis, has a long spine on the $\mathrm{c} 1$ plate, and such a spine has never been observed in P. dalei (Gu et al. 2013b; Kobayashi and Matsuoka 1995). Furthermore, contact between plates Sp and c1 was described by Kobayashi and Matsuoka (1995), resembling the situation in Scrippsiella (Lewis 1991), although P. imariensis is not closely related to the latter. Our SEM observations of $P$. imariensis, show that the Sp plate is short and does not contact plate c1 (Fig. 6E). Thus, we cannot exclude a possibility of incorrect observation by Kobayashi and Matsuoka (1995: fig. 23). Those authors also described the coccoid cell of $P$. imariensis, as characterised by wider processes $(1.5-2.2 \mu \mathrm{m}$ wide), and pointed out that this feature may be key to distinguishing coccoid cells of P. imariensis from P. dalei. However, the processes of P. imariensis vary (Fig. 5E-H). Thus, morphological traits of the coccoid cells do not allow for the unequivocal species distinction of $P$. dalei, $P$. dalei var. aciculiferum and $P$. imariensis, and molecular studies are required to identify those dinophytes to the species level and below.

\section{The Fossil Record of Ensiculiferaceae}

Two extant species of Ensiculiferaceae have a fossil record. The first occurrence of coccoid cells assigned to P. dalei is observed in the Upper Miocene of the Norwegian Sea (De Schepper et al. 2015, 2017), whilst there is a more or less continuous documentation of E. tyrrhenica $(=\dagger C$. bivalvum $)$ since the Upper Pliocene 
from the Mediterranean (Versteegh 1993). This evidence, and the short branch lengths in the phylogenies, suggest that Ensiculiferaceae evolved relatively late compared to other marine dinophytes (Žerdoner Čalasan et al. 2019; Chacón and Gottschling 2020). Moreover, there are a number of Neogene fossils that are morphologically similar to coccoid cells of extant Ensiculifera such as †Calciconus Streng, Banasová, D. Reháková \& H.Willems and †Cylindratus Banasová, Kopčáková \& D.Rehaková ex Streng, Banasová, D. Reháková \& H.Willems. They have an apical operculum that corresponds to a single plate equivalent (Streng et al. 2009). At least, some of these Neogene forms have survived until today, including $\dagger$ Follisdinellum splendidum G.Versteegh, $†$ Melodomuncula berlinensis G.Versteegh and †Praecalcigonellum schizosaeptum G.Versteegh (Montresor et al. 1994; Rubino et al. 2013, 2017; Zonneveld et al. 1999). However, none of these forms have been successfully cultivated, and reliable phylogenetic data are therefore not available.

The coccoid cells of E. mexicana are similar to significantly older fossils such as $\dagger$ Bicarinellum Deflandre (Keupp 1991; Zinßmeister et al. 2012), which exhibits a tabulation and a circular apical operculum equivalent to plate 3' (Streng et al. 2004). This archaeopyle type has been considered as ancestral to the combination operculum type present in Scrippsiella s.l. (Gottschling et al. 2008). The coccoid cells of E. mexicana with $\uparrow$ Bicarinellum cristatum Keupp from the lowermost Barremian to early Albian (Keupp 1982) possess other similarities to each other, such as a pentagonal outline in apical view, a prominent carina and a more or less flattened hypocyst. However, the coccoid cell of E. mexicana has a strongly oblate autophragm and a single-layered calcareous wall in contrast to $\uparrow$ Bicarinellum, which has a double-layered calcareous wall (Keupp 1991). We cannot preclude the possibility that more fossils (particularly obliquipithonelloids: Kohring et al. 2005) are assignable to Ensiculiferaceae, but this requires further careful taxonomic revision and comprehensive phylogenetic analysis.

The uniform characteristic tabulation and plate overlap pattern in the Ensiculiferaceae reflect evolutionary stability in these taxa, in contrast to the extreme variation known for Peridinium Ehrenb. and Protoperidinium Bergh. The plate overlap pattern in Ensiculiferaceae and Thoracosphaeraceae is similar to 
that of Triassic through Jurassic $\uparrow$ Phallocysteae Below (Below 1987), but even more so to the Cretaceous $\dagger$ Subtilisphaera terrula (Palaeoperidinioidea; Harding 1988). This suggests that the Ensiculiferaceae evolved from such ancestors and that their tabulation and overlap pattern have been conserved since then. However, we advise caution since sole morphological similarity can be misleading as for example, Caladoa arcachonensis Z.Luo, K.N.Mert. \& H.Gu also has identical tabulation and overlap as Scrippsiella, but it is genetically distinct (Luo et al. 2019). The morphology of the coccoid cells of Ensiculiferaceae is known to be much more variable than the equivalent thecate monadoid cells. Interestingly, similar conclusions can be drawn for Gonyaulax Diesing and Scrippsiella, which may indicate similar adaptive evolutionary mechanisms (Lewis 1991; Rochon et al. 2009).

\section{The Link Between Calcareous Dinophytes and Parasites}

Highly specialised organisms, such as parasites and endosymbionts, have evolved repeatedly and independently within various organismal groups in general and within dinophytes in particular. Because of many lost traits as well as many autapomorphies, the determination of their closest relatives is frequently only possible by comparison of molecular sequence data. It is particularly surprising that in our molecular phylogenies, the closest relative of an organism parasitising the ctenophore Mnemiopsis Agassiz, 1865 (Smith 2011; Smith et al. 2007) is a dinophyte that exhibits a calcareous coccoid stage during its life-history. Moreover, the organism shows no phylogenetic affinities to other parasite groups, even from the Peridiniales.

The parasitic species nesting within Ensiculifera is not the only one that shows phylogenetic affinities to the calcareous dinophytes: Amyloodinium E.-M.Br. \& Hovasse and Paulsenella Chatton are closely related to the pfiesterians of the T/Pf-clade (Kühn et al. 2005; Litaker et al. 1999), while Dubscquodinium Grassé is nested within Scrippsiella s.l., and Tintinnophagus Coats may represent an independent lineage within the complex relationships of the Thoracosphaeraceae (Coats et al. 2010). Two interpretations of this scattered distribution of parasites and other unusual life forms in the dinophyte molecular phylogenies are 
conceivable: 1. The evolution from phototrophic cells towards more specialised dinophytes with heterotrophic, endosymbiotic or parasitic nutrition has occurred independently several times; 2 . Knowledge of particular dinophyte species is incomplete, and life-history includes undiscovered parasitic stages. In particular, it is tempting to speculate for the Scrippsiella acuminata species complex, including morphologically indistinguishable but phylogenetically distinct ('cryptic') species (Coats et al. 2020; Gottschling et al. 2005; Gottschling and Söhner 2013; Montresor et al. 2003; Söhner et al. 2012; Zinßmeister et al. 2011), that the reproductively isolated units are differentiated by their association with respective, specific hosts (pers. comm. K.J.S. Meier; Kiel, Germany). Further research is required to clarify the complex biology and evolution of the calcareous dinophytes.

\section{Conclusions}

Our study clarifies the relationships of an important, though previously enigmatic, dinophyte species, $E$. mexicana, and provides evidence that Ensiculiferaceae are composed of three lineages. The assignment of species to generic names was inconsistent in the past, and a possible solution was to accept a single generic name, Ensiculifera. However, this solution does not acknowledge the notable diversity of coccoid cells that corresponds to the three lineages: 1 . Ensiculifera, characterised by a calcareous coccoid stage with an apical operculum; 2. Pentapharsodinium, having a coccoid stage with an organic wall and processes of varying lengths; 3. Matsuokaea, with a smooth organic-walled coccoid stage. As M. loeblichii, is not closely related to either Ensiculifera or Pentapharsodinium, we propose the new generic name Matsuokaea. This solution is preferred by those about to study primarily the coccoid stage of dinophytes but will be challenging for field protistologists, who need to attribute morphologically indistinguishable monadoid cells to one of the three taxa recognised here.

\section{Taxonomic Activity}


Ensiculiferaceae Zhun Li, Gottschling, K.N.Mert., H.Gu \& H.H.Shin, fam. nov.-Type: Ensiculifera Balech, Revista del Museo Argentino de Ciencias Naturales "Bernardino Rivadavia” (Hidrobiología) 2: 122. 1967.

Description: Dinophytes free-living, solitary, thecate. Monadoid cells bipesoid, orthoperidinioid with Kofoidean plate formula: Po, X, 4', 3a, 7", 5c, 5S, 5"', 2"'"; spine absent or present on the anterior sulcal plate or first cingular plate; chloroplasts present. Coccoid cells calcified or organic-walled. [http://phycobank.org/102091]

Ensiculifera Balech emended Zhun Li, K.N.Mert., H.Gu \& H.H.Shin-Type: Ensiculifera mexicana Balech, Revista del Museo Argentino de Ciencias Naturales "Bernardino Rivadavia" (Hidrobiología) 2: 120-122, figs 136-144. 1967.

Description: Monadoid cell broad with Kofoidean plate formula: Po, X, 4', 3a, 7", 5c, 5S, 5"', 2"'", slightly flattened dorsoventrally, cingulum subequatorial, descending; the plate Sp separated from cingulum. Coccoid cells with an inner organic layer, surrounded by a calcareous outer layer.

\section{Ensiculifera mexicana Balech emended Zhun Li, K.N.Mert., H.Gu \& H.H.Shin}

Description: Monadoid cell broad, slightly flattened dorsoventrally, without antapical horns or posterior notch; the thecal surface with many pores and small bumps; the cingulum subequatorial and descending, ends displaced by one cingulum width; the epitheca conical, with somewhat convex flanks, bipesoid, orthoperidinioid; the Po plate with a round apical pore, located centrally at the apex; the 1' plate rhombic, narrow; the plates $2^{\prime}$ and $4^{\prime}$ hexagonal; the spine attached to the first cingular plate. Coccoid cells roughly pentagonal in apical view, subrectangular in lateral view, with an inner organic layer, surrounded by a calcareous layer.

Remarks: This species has been related to "Pentadinellum oblatum" Keupp, a name not validly published (ICN Art. 44.1) and whose type is based on a coccoid cell. rRNA gene sequences of strains LMBE-JH1, 
LMBE-TY1, LMBE-TY2 and LMBE-UL1 (Table S1) were deposited in GenBank as entries MN821536MN821539, MN821542-MN821545 and MN821565-MN821568.

Ensiculifera tyrrhenica (Balech) Zhun Li, K.N.Mert., Gottschling, H.Gu \& H.H.Shin, comb. nov.

Basionym: Peridinium tyrrhenicum Balech, Helgoländer wissenschaftliche Meeresuntersuchungen 44: 390-391, figs 12-18. 1990.

Synonym: Pentapharsodinium tyrrhenicum (Balech) Montresor, Zingone \& D.Marino ex Head

Remark: This species has been related to $\dagger$ Calcicarpinum bivalvum G.Versteegh, whose type is based on a coccoid cell.

[http://phycobank.org/102092]

Ensiculifera jinhaensis (Zhun Li, M.S.Han \& H.H.Shin) Zhun Li, K.N.Mert., Gottschling, H.Gu \& H.H.Shin, comb. nov.

Basionym: Pentapharsodinium jinhaense Zhun Li, M.S.Han \& H.H.Shin in Zhun Li, H.H.Shin, W.A.Lim, T.Lee, Y.H.Yoon \& M.S.Han, Phycologia 54: 568-574, figs 1-27. 2015.

[http://phycobank.org/102093]

Pentapharsodinium Indel. \& A.R.Loebl. emended Zhun Li, K.N.Mert., H.Gu \& H.H.Shin - Type: Pentapharsodinium dalei Indel. \& A.R.Loebl., Japanese Journal of Phycology (Sôrui) 34: 158-159, figs 15, 7-8. 1986.

Description: Monadoid cells orthoperidinioid with Kofoidean plate formula: Po, X, 4', 3a, 7", 5c, 5S, 5"', $2^{\prime \prime \prime \prime}$; the cingulum subequatorial and descending; the plate Sp separated from cingulum. Coccoid cell spherical to ovoid, acapsulate, with an outer organic layer; the surface with many capitate processes.

Pentapharsodinium imariense (S.Kobayashi \& Matsuoka) Zhun Li, K.N.Mert., Gottschling, H.Gu \& 


\section{H.H.Shin, comb. nov.}

Basionym: Ensiculifera imariensis S.Kobayashi \& Matsuoka, Journal of Phycology 31: 147-151, figs 1-23. 1995.

[http://phycobank.org/102094]

Remark: ITS sequences of strains Eng10, TIO278a, TIO445, TIO526 (Table S1) were deposited in GenBank as entries MN821554-MN821557.

Matsuokaea Zhun Li, K.N.Mert., H.Gu \& H.H.Shin, gen. nov.-Type: Matsuokaea loeblichii (El.R.Cox \& H.J.Arn.) Zhun Li, K.N.Mert., H.Gu \& H.H. Shin, comb. nov.

Description: Monadoid cell broad, with Kofoidean plate formula: Po, X, 4', 3a, 7", 5c, 5S, 5"', 2'"', slightly flattened dorsoventrally; the cingulum subequatorial and descending; the spine absent; the single rodshaped eyespot located on the right side of the sulcus; the plate Sp separated from cingulum. Coccoid cells spherical to ovoid; the surface smooth; an outer layer organic.

Etymology: In honour of Prof. Kazumi Matsuoka (Nagasaki), a pioneer in the study of armoured dinophyte taxonomy and the biological links between monadoid and coccoid cells.

[http://phycobank.org/102095]

Matsuokaea loeblichii (El.R.Cox \& H.J.Arn.) Zhun Li, K.N.Mert., H.Gu \& H.H.Shin, comb. nov. Basionym: Ensiculifera loeblichii El.R.Cox \& H.J.Arn. in P.C.Parker \& R.M.Br., Contributions in Phycology: 121, 123-124, figs 1-34. 1971.

Synonyms: Pentapharsodinium trachodium Indel. \& A.R.Loebl.; Peridinium loeblichii (El.R.Cox \& H.J.Arn.) Dale

[http://phycobank.org/102096]

Remark: ITS and rRNA gene sequences of strain LMBE-JH2 (Table S1) were deposited in GenBank as entries MN821558, MN821571, MN821541. 


\section{Key}

Based on molecular phylogenetics and morphologies considering life-history, the following key includes the eight species of Ensiculiferaceae, which we currently accept and for which sequence data are available.

1a. Coccoid cell with calcareous wall

1b. Coccoid cell with organic wall

2a. Archaeopyle circular or subcircular

2b. Archaeopyle intercalary, theropylic

3a. Coccoid cells with longer or shorter protuberances

3b. Coccoid cells with smooth wall

4a. Spine attached to plate $\mathrm{c} 1$ of monadoid cell

4b. No spine attached to plate $\mathrm{c} 1$ of monadoid cell

5a. Calcareous wall ridged

5b. Calcareous wall not ridged

6a. Spine attached to plate $\mathrm{c} 1$ or plate $\mathrm{Sa}$ of monadoid cell

6b. No spine attached to plate $\mathrm{c} 1$ or plate $\mathrm{Sa}$ of monadoid cell

7a. Spine attached to plate $\mathrm{c} 1$ of monadoid cell

7b. Spine attached to plate Sa of monadoid cell
Matsuokaea loeblichii

Ensiculifera mexicana

Ensiculifera tyrrhenica

Ensiculifera carinata

Ensiculifera jinhaensis

7

Pentapharsodinium dalei

Pentapharsodinium imariense

Pentapharsodinium dalei var. aciculiferum

\section{Methods}

Sampling, cultivation and light microscopy: Surface sediment samples were collected from the Tongyeong coastal area and Jinhae Bay (Korea), Nagasaki Bay (Japan), Comau Fjord (Chile) and Opua Bay (Queen Charlotte Sound, New Zealand). The sediment analysis was conducted using the methods from 
Li et al. (2015a). The isolated coccoid cells were identified at $\times 400$ magnification with an inverted transmitted light microscope Primo Vert (Zeiss, Germany) and transferred to individual wells of 96-well tissue culture plates (Eppendorf, Germany) containing $200 \mu \mathrm{L}$ of sterile F/2-Si culture medium (Marine Water Enrichment Solution; Sigma-Aldrich, USA-MO; Guillard 1975) with a salinity of 32. The inoculated coccoid cells were incubated at $20^{\circ} \mathrm{C}$ under $100 \mu \mathrm{mol}$ photons $\mathrm{m}^{-2} \mathrm{~s}^{-1}$ provided by cool-white fluorescent tubes on a 14:10 h light:dark cycle and were checked daily until monadoid cells were observed. Plankton samples were collected with a plankton net (mesh size $20 \mu \mathrm{m}$ ) in a shallow natural reservoir used for oyster cleansing before commercialisation (water depth 1.2-1.5 m) close to Meyran (France), off the coast of Liverpool (United Kingdom), in the western North Atlantic, the Gulf of Mexico off the coast of Louisiana (USA), the East China Sea, along the south coast of Korea and East Sea/Sea of Japan (Table S1). Single cells were isolated using a capillary pipette and inoculated into individual wells of 48 -well culture plates (Eppendorf) filled with $300 \mu \mathrm{L}$ sterile F/2-Si culture medium. The cells were incubated at $20{ }^{\circ} \mathrm{C}$ and ca. $100 \mu \mathrm{mol}$ photons $\mathrm{m}^{-2} \mathrm{~s}^{-1}$ cool-white illumination under a 14:10 h light: dark photo-cycle. All strains are currently held in the culture collection at the Library of Marine Samples (Korea Institute of Ocean Science and Technology; http://lims.kiost.ac.kr; Supplementary Material Table S1).

Light micrographs were taken using an ultra-high resolution digital camera (DS-Ri2; Nikon, Japan) on an upright microscope (ECLIPSE Ni; Nikon). For fluorescence microscopy, approximately $1 \mathrm{~mL}$ of live, healthy material was transferred to a $1.5 \mathrm{~mL}$ microcentrifuge tube, and SYTOX ${ }^{\circledR}$ Green Nucleic Acid Stain (Molecular Probes, USA-OR) was added at a final concentration of $1.0 \mu \mathrm{M}$. The cells were incubated in the dark at room temperature for 30 min, observed through a Zeiss Filterset (emission: BP 450-490; beam splitter: FT 510) and photographed at $\times 400$ or $\times 1000$ magnification using an AxioCam MRc digital camera on an upright microscope (Axio Imager 2, Zeiss). The Kofoidean system was used to designate thecal plates (Taylor 1980, Fensome et al. 1993). The sulcal plate labelling followed Balech (1980).

Scanning electron microscopy (SEM): For SEM samples from Korea, $2 \mathrm{~mL}$ of mid-exponentially growing strains were fixed with Lugol's iodine solution $\left(2.0 \%\right.$ final concentration) at $4{ }^{\circ} \mathrm{C}$ for $5 \mathrm{~h}$. The 
samples were then washed twice with deionised water and dehydrated in a graded ethanol series (10-99.9\% in eight steps) for $15 \mathrm{~min}$ at each step. The samples were critical point dried using as SPI-Dry Regular Critical Point Dryer (SPI Supplies, USA-PA) with liquid $\mathrm{CO}_{2}$. Finally, the samples were coated with platinum and examined at a voltage of $5 \mathrm{kV}$ under a JEOL JSM 7600F field emission SEM (JEOL, Japan). Coccoid cells were collected with a micropipette from the sediment samples and strains, transferred onto graphite-covered stubs and left to dry at room temperature. Energy-dispersive X-ray spectroscopy (EDS) of these uncoated coccoid cells was performed in a field emission SEM JEOL JSM 7600F equipped with an Energy Dispersive Spectroscopy System (Oxford Instruments, Germany).

For SEM samples from Opua Bay (New Zealand), monadoid and coccoid cells were isolated using a micropipette to polycarbonate membrane filters (Millipore, Billerica, MA, USA, GTTP Isopore, $0.22 \mu \mathrm{m}$ pore size). These were rinsed with distilled water and dehydrated in a graded ethanol series (30 to 100\% in six steps), critical-point-dried with $\mathrm{CO}_{2}$ (CPDBal-Tec 030), glued onto a stub and sputter-coated with gold. The images were made with a Zeiss SIGMA300 Gemini field emission SEM at the Station de Biologie Marine (Concarneau, France).

DNA extraction, PCR conditions and DNA sequencing: Genomic DNA was extracted from $1 \mathrm{~mL}$ of exponentially growing strains using DNeasy Plant mini kits (Qiagen, USA-CA) following the manufacturer's instructions. Small subunit (SSU) ribosomal RNA (rRNA), internal transcribed spacer (ITS) region and D1-D3 large subunit (LSU) rRNA gene sequences were amplified using the primers specified in Supplementary Material Table S2. Polymerase chain reactions (PCR) were carried out in a $1 \times \mathrm{PCR}$ buffer which contained less than $0.1 \mu \mathrm{g}$ genomic DNA template, $0.3 \mu \mathrm{M}$ of each primer, $1.25 \mathrm{U}^{\text {PrimeSTAR }}{ }^{\circledR}$ GXL DNA polymerase (Takara Bio, Japan) and PCR-grade water to a final volume of $50 \mu \mathrm{L}$. Reactions were conducted using a T100 ${ }^{\mathrm{TM}}$ Thermal Cycler (Bio-Rad, USA-CA) with the following conditions: $95^{\circ} \mathrm{C}$ for $4 \mathrm{~min}$, followed by 30 cycles of $98^{\circ} \mathrm{C}$ for $10 \mathrm{~s}, 55^{\circ} \mathrm{C}$ for $30 \mathrm{~s}$ and $68{ }^{\circ} \mathrm{C}$ for $2 \mathrm{~min}$, and one cycle of $72{ }^{\circ} \mathrm{C}$ for $5 \mathrm{~min}$. Successful PCR amplification was confirmed by $1.0 \%$ agarose gel electrophoresis. The PCR products were purified with QIAquick PCR purification kits (Qiagen). Direct Sanger sequencing was 
performed using the ABI PRISM® Big DyeTM Terminator Cycle Sequencing Ready Reaction Kit (Applied Biosystems, USA-CA), and the traces were examined for polymorphisms.

Alignment and phylogenetic analyses: Sequences were viewed and assembled in DNABaser version 4.36 (http://www.dnabaser.com) and aligned using MAFFT v6.624b online version 7 (https://mafft.cbrc.jp/alignment/server/; Katoh et al. 2017) and the Q-INS-I option to consider rRNA secondary structures. The alignments were manually edited, and ambiguously aligned characters were excluded using MEGA version 7.0 (Kumar et al. 2016). The separate SSU, ITS and LSU alignments were concatenated using SequenceMatrix version 1.8 (Vaidya et al. 2011). Phylogenetic inference in our work is based on previous studies (e.g., Gottschling et al. 2005; Gottschling and Söhner 2015; Kretschmann et al. 2018). The similarity matrix of pairwise $p$-distance for the ITS dataset was calculated using MEGA as well. The final alignment of the ITS dataset consisted of 82 taxa. The sequences from other species of Amphidomataceae, Heterocapsaceae, Kryptoperidiniaceae and Thoracosphaeraceae were used as outgroups. The alignment of the concatenated dataset consisted of 59 taxa for SSU+ITS+LSU (Supplementary Material Table S1), and sequences from Amphidomataceae and Heterocapsaceae species were used as an outgroup based on previous phylogenetic analyses with a broad taxon sample of dinophytes (Gottschling et al. 2020; Gu et al. 2013a).

Phylogenetic trees for the sequence alignments (ITS and SSU+ITS+LSU) were inferred from maximum likelihood (ML) analyses (using RaxML version 8: Stamatakis 2014) and Bayesian inference (using MrBayes version 3.2: Ronquist et al. 2012). The general time reversible (GTR) model with parameters accounting for $\gamma$-distributed rate variation across sites $(\mathrm{G})$ was used in all analyses taking into account 6-class gamma. The $\mathrm{GTR}+\mathrm{G}$ substitution model was selected using the Akaike information criterion as implemented in jModelTest version 2.1.4 (Darriba et al. 2012). Bootstrap analyses for both datasets were carried out for ML with 1,000 replicates to evaluate statistical reliability. The Markov chain Monte Carlo method was used with four runs for 10 million generations, sampling every 100 generations. A majority rule consensus tree was created in order to examine the posterior probabilities of each clade. 
The final trees were visualised with FigTree v1.4.4.

\section{Author statement}

Zhun Li: conceptual work, strain isolation, LM and SEM, PCR and sequencing, data analysis, drafting and editing of the manuscript, species descriptions, Kenneth Neil Mertens: drafting and editing of the manuscript, data analysis, field sampling, strain isolation, species description, morphologic analysis of established species, LM and SEM, Marc Gottschling: molecular phylogenetics, data analysis, review and editing of the manuscript, Haifeng Gu: field sampling, strain isolation, PCR and sequencing, data analysis, review and editing of the manuscript. Sylvia Söhner: field sampling, PCR and sequencing, review and editing of the manuscript, Andrea M. Price: field sampling, review and editing of the manuscript, Fabienne Marret: field sampling, review and editing of the manuscript, Vera Pospelova: sample processing, review and editing of the manuscript, Kirsty F. Smith: field sampling, PCR and sequencing, review and editing of the manuscript, Consuelo Carbonell-Moore: image analysis, review and editing of the manuscript, Elisabeth Nézan: review and editing of the manuscript, Gwenael Bilien: PCR and sequencing, review and editing of the manuscript, Hyeon Ho Shin: conceptual work, species descriptions, data analysis, drafting and editing manuscript.

\section{Declaration of interests}

The authors declare that they have no known competing financial interests or personal relationships that could have appeared to influence the work reported in this paper.

\section{Funding}

This work was supported by the KRIBB Research Initiative Program, the Marine Biotechnology Program funded by the Ministry of Oceans and Fisheries of the Korean Government (20170431), and KIOST project (PE99821). The Regional Council of Brittany, the General Council of Finistère, the urban community of Concarneau Cornouaille Agglomération and the European Regional Development Fund (ERDF) are acknowledged for funding the Sigma 300 FE-SEM at the Concarneau Marine Station. JSPS stipend for Sylvia Söhner. Partial funding for this research was provided by a Natural Sciences and Engineering Research Council of Canada (NSERC) Discovery grant to VP. This work was supported in part by the Zuckerman STEM Leadership Program through a postdoctoral fellowship to AMP, and by a 
Catalyst:seeding grant (CSG-CAW1601) to KS and KNM.

\section{Conflict of Interest}

The authors declare no conflicts of interest associated with this manuscript.

\section{Acknowledgements}

David Wall is acknowledged for sharing information on his incubation experiments. Robert A. Fensome and three anonymous reviewers are thanked for constructive suggestions that greatly improved the manuscript. We also thank Francine Beaujot and the Huinay Scientific Field Station (the Fundación San Ignacio del Huinay) for collecting samples from Comau Fjord, Chile.

\section{References}

Andersen RA (2018) Report of the Nomenclature Committee for Algae: 18. Taxon 67:437-438

Balech E (1967) Dinoflagelados nuevos o interesantes del Golfo de Mexico y Caribe. Rev Mus Argent Cienc Nat 2:77-144

Balech E (1980) On thecal morphology of dinoflagellates with special emphasis on circular and sulcal plates. An Centro Cienc Del Mar y Limnol Univ Nav Autón México 7:57-68

Balech E (1988) Los dinoflagelados del Atlántico sudoccidental. Publ. Espec., Inst. Español Oceanogr. 1:1-310

Below R (1987) Evolution und Systematik von Dinoflagellaten-Zysten aus der Ordnung Peridiniales I. Allgemeine Grundlagen und Subfamilie Rhaetogonyaulacoideae (Familie Peridiniaceae). Palaeontogr. Abt. B 205:1-164.

Bolli HM (1974) Jurassic and Cretaceous Calcisphaeridulae from DSDP Leg 27, Eastern Indian Ocean. Init Rep DSDP 27:843-907.

Cachon J, Cachon M (1987) Parasitic Dinoflagellates. In Taylor FJR (ed) The Biology of Dinoflagellates, Blackwell, Oxford, pp 571-610 
Chacón J, Gottschling M (2020) Dawn of the dinophytes: A first attempt to date origin and diversification of harmful algae. Harmful Algae 97:101871

Chatton É (1920) Les péridiniens parasites. Morphologie, réproduction, éthologie. Arch zool exp. gen 59: $1-475$

Chatton É, Grassé P-P (1952) Classe des dinoflagellés ou péridiniens. In Grassé P-P (ed), Phylogénie Protozoaires : Généralités, Flagellés, Masson, Paris, pp 309-406

Coats DW (1999) Parasitic life styles of marine dinoflagellates. J Eukaryot Microbiol 57:402-409

Coats DW, Kim S, Bachvaroff TR, Handy SM, Delwiche CF (2010) Tintinnophagus acutus n. g., n. sp. (Phylum Dinoflagellata), an ectoparasite of the ciliate Tintinnopsis cylindrica Daday 1887, and its relationship to Duboscquodinium collini Grassé 1952. J Eukaryot Microbiol 57:468-482

Coats DW, Choi J, Jung JH, Kim YO, Lu Y \& Nielsen LT (2020) Mixotrophic scrippsielloid dinoflagellates prey on tintinnid ciliates. Aquat Ecosyst Health Manag 23:69-78

Cox ER, Arnott HJ (1971) The Ultrastructure of the Theca of the Marine Dinoflagellate, Ensiculifera loeblichii sp. nov. In Parker PC, Brown RM (eds), Contributions in Phycology, Allen Press, Lawrence, Kansas, USA, pp 121-136.

D'Onofrio G, Marino D, Bianco L, Busico E, Montresor M (1999) Toward an assessment on the taxonomy of dinoflagellates that produce calcareous cysts (Calciodinelloideae, Dinophyceae): A morphological and molecular approach. J Phycol 35:1063-1078

Dale B (1977) New observations on Peridinium faeroense Paulsen (1905), and classification of small orthoperidinioid dinoflagellates. Br Phycol J 12:241-253

Dale B (1983) Dinoflagellate Resting Cysts:"Benthic Plankton". In Fryxell GA (ed), Survival Strategies of the Algae, Cambridge University Press, Cambridge, pp 69-136

Darriba D, Taboada GL, Doallo R, Posada D (2012) jModelTest 2: more models, new heuristics and parallel computing. Nat Methods 9:772

De Schepper S, Schreck M, Beck KM, Matthiessen J, Fahl K, Mangerud G (2015) Early Pliocene onset of modern Nordic Seas circulation related to ocean gateway changes. Nat Commun 6:8659.

De Schepper S, Beck KM, Mangerud G (2017) Late Neogene dinoflagellate cyst and acritarch biostratigraphy for Ocean Drilling Program Hole 642B, Norwegian Sea. Rev Palaeobot Palynol 236: $12-32$

Deflandre G (1949) Les Calciodinellidés Dinoflagellés fossiles à thèque calcaire. Le Botaniste 34:191219

Elbrächter M, Gottschling M, Hildebrand-Habel T, Keupp H, Kohring R, Lewis J, Meier KS, Montresor M, Streng M, Versteegh GJM (2008) Establishing an agenda for calcareous 
dinoflagellate research (Thoracosphaeraceae, Dinophyceae) including a nomenclatural synopsis of generic names. Taxon 57:1289-1303

Ellegaard M, Daugbjerg N, Rochon A, Lewis J, Harding I (2003) Morphological and LSU rDNA sequence variation within the Gonyaulax spinifera-Spiniferites group (Dinophyceae) and proposal of G. elongata comb. nov and G. membranacea comb. nov. Phycologia 42:151-164

Fensome RA, Taylor FJR, Norris G, Sarjeant WAS, Wharton DI, Williams GL (1993) A Classification of Living and Fossil Dinoflagellates. Micropaleontology Special Paper No 7, American Museum of Natural History, $351 \mathrm{p}$

Gómez F, Moreira D, López-García P (2009) Life cycle and molecular phylogeny of the dinoflagellates Chytriodinium and Dissodinium, ectoparasites of copepod eggs. Europ J Protistol 45:260-270

Gómez F, Moreira D, López-García P (2010) Molecular phylogeny of noctilucoid dinoflagellates (Noctilucales, Dinophyceae). Protist 161:466-478

Gottschling M, Keupp H, Plötner J, Knop R, Willems H, Kirsch M (2005) Phylogeny of calcareous dinoflagellates as inferred from ITS and ribosomal sequence data. Mol Phylogenet Evol 36:444-455.

Gottschling M, McLean TI (2013) New home for tiny symbionts: Dinophytes determined as Zooxanthella are Peridiniales and distantly related to Symbiodinium. Mol Phylogenet Evol 67:217-222

Gottschling M, Söhner S (2013) An updated list of generic names in the Thoracosphaeraceae. Microorganisms 1:122-136

Gottschling M, Kretschmann J, Žerdoner Čalasan A (2017) Description of Peridiniopsidaceae (Peridiniales, Dinophyceae). Phytotaxa 299:293-296

Gottschling M, Söhner S, Zinßmeister C, John U, Plötner J, Schweikert M, Aligizaki K, Elbrächter M (2012) Delimitation of the Thoracosphaeraceae (Dinophyceae), including the calcareous dinoflagellates, based on large amounts of ribosomal RNA sequence data. Protist 163:15-24

Gu H, Wang Y (2007) The first record of Ensiculifera Balech and Fragilidium Balech (Dinophyceae) from Chinese coast. Acta Phytotax Sin 45:828-840

Gu H, Luo Z, Liu TT, Lan DZ (2013c) Morphology and phylogeny of Scrippsiella enormis sp. nov. and $S$. cf. spinifera (Peridiniales, Dinophyceae) from the China Sea. Phycologia 52:182-190

Gu H, Luo Z, Zeng N, Lan B, Lan D (2013b) First record of Pentapharsodinium (Peridiniales, Dinophyceae) in the China Sea, with description of Pentapharsodinium dalei var. aciculiferum. Phycol Res 61:256-267

Gu H, Kirsch M, Zinßmeister C, Söhner S, Meier KJS, Liu T, Gottschling M (2013a) Waking the dead: Morphological and molecular characterization of extant $†$ Posoniella tricarinelloides (Thoracosphaeraceae, Dinophyceae). Protist 164:583-597 
Guillard RR (1975) Culture of Phytoplankton for Feeding Marine Invertebrates. In Smith WL, Chanley MH (eds) Culture of Marine Invertebrate Animals. Plenum Press, New York, pp 29-60

Harding IC (1988) Thecamorphic features of the early Cretaceous dinocyst Subtilisphaera terrula. Neues Jahrbuch für Geologie und Paläontologie, Monatshefte 1:49-63

Hildebrand-Habel T, Streng M (2003) Calcareous dinoflagellate associations and Maastrichtian-Tertiary climatic change in a high-latitude core (ODP Hole 689B, Maud Rise, Weddell Sea). Palaeogeogr Palaeoclimatol Palaeoecol 197:293-321

Hoppenrath M (2017) Dinoflagellate taxonomy - a review and proposal of a revised classification. Mar Biodiv 47:381-403

Indelicato S, Loeblich III AR (1986) A revision of the marine peridinioid genera (Pyrrhophyta) utilizing hypothecal-cingular plate relationships as a taxonomic guideline. Jpn J Phycol 34:153-162

Janofske D (1992) Kalkiges Nannoplankton, insbesondere kalkige Dinoflagellaten-Zysten der alpinen Ober-Trias: Taxonomie, Biostratigraphie und Bedeutung für die Phylogenie der Peridiniales. Berliner geowiss. Abh Reihe A (E) 4:1-53

Janofske D (1996) Ultrastructure types in Recent "calcispheres". Bull Inst océanogr (Monaco) 14:295303.

Karwath B (2000) Ecological studies on living and fossil calcareous dinoflagellates of the equatorial and tropical Atlantic Ocean. Berichte aus dem Fachbereich Geowissenschaften, Universität Bremen 152:1-175

Katoh K, Rozewicki J, Yamada KD (2017) MAFFT online service: multiple sequence alignment, interactive sequence choice and visualization. Brief Bioinform bbx108.

Kempton JW, Wolny J, Tengs T, Rizzo P, Morris R, Tunnell J, Scott P, Steidinger K, Hymel SN, Lewitus AJ (2002) Kryptoperidinium foliaceum blooms in South Carolina: a multi-analytical approach to identification. Harmful Algae 1:383-392

Keupp H (1981) Die kalkigen Dinoflagellaten-Zysten der borealen Unter-Kreide (Unter-Hauterivillm bis Unter-Albium). Facies 5:1-190

Keupp H (1991) Fossil Calcareous Dinoflagellate Cysts. In Riding R (ed) Calcareous Algae and Stromatolites. Springer, Berlin, pp 267-286

Kobayashi S, Matsuoka K (1995) A new species of Ensiculifera, E. imariense (Dinophyceae), producing organic-walled cysts. J Phycol 31:147-152

Kogame K, Horiguchi T, Masuda M (1999) Phylogeny of the order Scytosiphonales (Phaeophyceae) based on DNA sequences of rbcL, partial rbcS, and partial LSU nrDNA. Phycologia 38:496-502

Kohring R, Gottschling M, Keupp H (2005) Examples for character traits and palaeoecological 
significance of calcareous dinoflagellates. Paläont Z 79:79-91

Kretschmann J, Žerdoner Čalasan A, Gottschling M (2018a) Molecular phylogenetics of dinophytes harboring diatoms as endosymbionts (Kryptoperidiniaceae, Peridiniales), with evolutionary interpretations and a focus on the identity of Durinskia oculata from Prague. Mol Phylogenet Evol 118:392-402

Kretschmann J, Owsianny PM, Žerdoner Čalasan A, Gottschling M (2018b) The hot spot in a cold environment: Puzzling Parvodinium (Peridiniopsidaceae, Peridiniales) from the Polish Tatra Mountains. Protist 169:206-230

Kretschmann J, Elbrächter M, Zinßmeister C, Söhner S, Kirsch M, Kusber W-H, Gottschling M (2015) Taxonomic clarification of the dinophyte Peridinium acuminatum Ehrenb., $\equiv$ Scrippsiella acuminata comb. nov. (Thoracosphaeraceae, Peridiniales). Phytotaxa 220:239-256

Kumar S, Stecher G, Tamura K (2016) MEGA7: Molecular Evolutionary Genetics Analysis Version 7.0 for Bigger Datasets. Mol Biol Evol 33:1870-1874

Levy MG, Litaker RW, Goldstein RJ, Dykstra MJ, Vandersea MW, Noga EJ (2007) Piscinoodinium, a fish-ectoparasitic dinoflagellate, is a member of the class Dinophyceae, subclass Gymnodiniphycidae: Convergent evolution with Amyloodinium. J Parasitol 93:1006-1015

Lewis J (1991) Cyst-theca relationships in Scrippsiella (Dinophyceae) and related orthoperidinioid genera. Bot Mar 34:91-106

Li Z, Shin HH, Lim WA, Lee T, Yoon YH, Han MS (2015b) Morphology and phylogeny of Pentapharsodinium jinhaense sp. nov. (Dinophyceae) producing a calcareous resting cyst. Phycologia 54:566-577

Li Z, Matsuoka K, Shin HH, Kobayashi S, Shin K, Lee T, Han M-S (2015a) Brigantedinium majusculum is the cyst of Protoperidinium sinuosum (Protoperidiniaceae, Dinophyceae). Phycologia 54:517-529

Licea S, Zamudio ME, Luna R, Soto J (2004) Free-living dinoflagellates in the southern Gulf of Mexico: Report of data (1979-2002). Phycol Res 52:419-428

Litaker RW, Tester PA, Colorni A, Levy MG, Noga EJ (1999) The phylogenetic relationship of Pfiesteria piscicida, Cryptoperidiniopsoid sp. Amyloodinoum ocellatum and a Pfiesteria-like dinoflagellate to other dinoflagellates and apicomplexans. J Phycol 35:1379-1389

Luo Z, Mertens KN, Nézan E, Gu L, Pospelova V, Thoha H, Gu H (2019) Morphology, ultrastructure and molecular phylogeny of cystproducing Caladoa arcachonensis gen. et sp. nov. (Peridiniales, Dinophyceae) from France and Indonesia. Eur J Phycol 54:235-248

Luo Z, Krock B, Mertens KN, Nézan E, Chomerat N, Billen G, Tillmann U, Gu H (2017) Adding new 
pieces to the Azadinium (Dinophyceae) diversity and biogeography puzzle: Non-toxigenic Azadinium zhuanum sp. nov. from China, toxigenic A. poporum from the Mediterranean, and a nontoxigenic A. dalianense from the French Atlantic. Harmful Algae 66:65-78

Luo Z, Mertens KN, Bagheri S, Aydin H, Takano Y, Matsuoka K, McCarthy FMG, Gu H (2016) Cyst-theca relationship and phylogenetic positions of Scrippsiella plana sp. nov. and S. spinifera (Peridiniales, Dinophyceae). Eur J Phycol 51:188-102

Matsuoka K, Head MJ (2013) Clarifying Cyst-motile Stage Relationships in Dinoflagellates, In Lewis JM, Marret F, Bradley L (eds) Biological and Geological Perspectives of Dinoflagellates. The Micropalaeontological Society, Special Publications. Geological Society, London, pp 325-350

Matsuoka K, Kobayashi S, Gains G (1990) A new species of the genus Ensiculifera (Dinophyceae); its cyst and motile forms. Bull Plankton Soc Japan 37:127-143

Mertens KN, Yamaguchi A, Takano Y, Pospelova V, Head MJ, Radi T, Pieńkowski AJ, de Vernal A, Kawami H, Matsuoka K (2013) A new heterotrophic dinoflagellate from the North-eastern Pacific, Protoperidinium fukuyoi: cyst-theca relationship, phylogeny, distribution and ecology. J Eukaryot Microbiol 60:545-563

Moestrup Ø, Daugbjerg N (2007) On Dinoflagellate Phylogeny and Classification. In Brodie J, Lewis J (eds) Unravelling the Algae, the Past, Present, and Future of Algal Systematics. CRC press, Boca Raton, pp 215-230

Moldrup M, Moestrup Ø, Hansen PJ (2013) Loss of phototaxis and degeneration of an eyespot in longterm algal cultures: Evidence from ultrastructure and behaviour in the dinoflagellate Kryptoperidinium foliaceum. J Eukaryot Microbiol 60:327-334

Montresor M, Zingone A, Marino D (1993) The calcareous resting cyst of Pentapharsodinium tyrrhenicum comb. nov. (Dinophyceae). J Phycol 29:223-230

Montresor M, Sgrosso S, Procaccini G, Kooistra WHCF (2003) Intraspecific diversity in Scrippsiella trochoidea (Dinophyceae): evidence for cryptic species. Phycologia 42:56-70

Netzel H, Dürr G (1984) Dinoflagellate Cell Cortex. In Spector DL (ed) Dinoflagellates. Academic Press Inc. (London) Ltd., Orlando (Florida), pp 43-105

Okolodkov YB, Gárate-Lizárraga I (2006) An annotated checklist of dinoflagellates (Dinophyceae) from the Mexican Pacific. Acta Bot Mex 74:1-154

Probert I, Siano R, Poirier C, Decelle J, Biard T, Tuji A, Suzuki N, Not F (2014) Brandtodinium gen. nov. and B. nutricula comb. nov. (Dinophyceae), a dinoflagellate commonly found in symbiosis with polycystine radiolarians. J Phycol 50:388-399

Rochon A, Lewis J, Ellegaard M, Harding IC (2009) The Gonyaulax spinifera (Dinophyceae) “complex": 
Perpetuating the paradox? Rev Palaeobot Palynol 155:52-60

Ronquist F, Teslenko M, van der Mark P, Ayres DL, Darling A, Hohna S, Larget B, Liu L, Suchard MA, Huelsenbeck JP (2012) MrBayes 3.2: Efficient bayesian phylogenetic inference and model choice across a large model space. Syst Biol 61:539-542

Saburova M, Polikarpov I, Al-Yamani F (2012) First record of Kryptoperidinium foliaceum (Dinophyceae: Peridiniales) from a hypersaline environment in Kuwait, north-western Arabian Gulf. Mar Biodivers Rec 5: e104.

Shin HH, Baek SH, Li Z, Han MS, Oh SJ, Youn SH, Kim YS, Kim D, Lim WA (2014) Resting cysts, and effects of temperature and salinity on the growth of vegetative cells of the potentially harmful species Alexandrium insuetum Balech (Dinophyceae). Harmful Algae 39:175-184

Skovgaard A, Salomonsen XM (2009) Blastodinium galatheanum sp. nov. (Dinophyceae) a parasite of the planktonic copepod Acartia negligens (Crustacea, Calanoida) in the central Atlantic Ocean. Eur J Phycol 44:425-438

Smith KD (2011) A parasitic dinoflagellate of the ctenophore Mnemiopsis sp. Master's Thesis, Auburn University, Auburn, AL, USA. https://etd.auburn.edu/xmlui/handle/10415/2834

Smith KD, Dodson M, Santos S, Gast R, Rogerson A, Sullivan B, Moss AG (2007) Pentapharsodinium tyrrhenicum is a parasitic dinoflagellate of the ctenophore Mnemiopsis leidyi. J Phycol 43:37-37

Stamatakis A (2014) RAxML version 8: a tool for phylogenetic analysis and post-analysis of large phylogenies. Bioinformatics 30:1312-1313

Streng M, Hildebrand-Habel T, Willems H (2004) A proposed classification of archeopyle types in calcareous dinoflagellate cysts. J Paleontol 78:456-483

Takano Y, Horiguchi T (2006) Acquiring scanning electron microscopical, light microscopical and multiple gene sequence data from a single dinoflagellate cell. J Phycol 42:251-256

Taylor FJR (1980) On dinoflagellate evolution. Biosystems 13: 65-108

Tillmann U, Hoppenrath M, Gottschling M, Kusber W-H, Elbrächter M (2017) Plate pattern clarification of the marine dinophyte Heterocapsa triquetra sensu Stein (Dinophyceae) collected at the Kiel Fjord (Germany). J Phycol 53:1305-1324

Turland NJ, Wiersema JH, Barrie FR, Greuter W, Hawksworth DL, Herendeen PS, Knapp S, Kusber W-H, Li D-Z, Marhold K, May TW, McNeill J, Monro AM, Prado J, Price MJ, Smith GF (2018) International Code of Nomenclature for algae, fungi, and plants (Shenzhen Code) adopted by the Nineteenth International Botanical Congress Shenzhen, China, July 2017. Koeltz Botanical Books, Glashütten, $254 \mathrm{p}$

Vaidya G, Lohman DJ, Meier R (2011) SequenceMatrix: concatenation software for the fast assembly of 
multi-gene datasets with character set and codon information. Cladistics 27:171-180

Versteegh GJM (1993) New Pliocene and Pleistocene calcareous dinoflagellate cysts from southern Italy and Crete. Rev Palaeobot Palynol 78:353-380

Wall D, Dale B (1968) Quaternary calcareous dinoflagellates (Calciodinellidae) and their natural affinities. J Paleontol 42:1395-1408

Wall D, Guillard RRL, Dale B, Swift E, Watabe N (1970) Calcitic resting cysts in Peridinium trochoideum (Stein) Lemmermann, an autotrophic marine dinoflagellate. Phycologia 9:151-156

Wanner J (1940) Gesteinsbildende Foraminiferen aus Malm und Unterkreide des östlichen Ostindischen Archipels. Paläont Z 22:75-99

White TJ, Bruns T, Lee S, Taylor J (1990) Amplification and Direct Sequencing of Fungal Ribosomal RNA Genes for Phylogenetics. In Innis MA, Gelfand DH, Sninsky JJ, White TJ (eds) PCR Protocols: a Guide to Methods and Applications. Academic Press, New York, pp 315-322

Yamaguchi A, Horiguchi T (2005) Molecular phylogenetic study of the heterotrophic dinoflagellate genus Protoperidinium (Dinophyceae) inferred from small subunit rRNA gene sequences. Phycol Res 53:3042

Žerdoner Čalasan A, Kretschmann J, Gottschling M (2019): They are young, and they are many: Dating freshwater lineages in unicellular dinophytes. Environ Microbiol 21:4125-4135

Zinßmeister C, Söhner S, Kirsch M, Facher E, Meier KJS, Keupp H, Gottschling M (2012) Same but different: Two novel bicarinate species of extant calcareous dinophytes (Thoracosphaeraceae, Peridiniales) from the Mediterranean Sea. J Phycol 48:1107-1118

Zonneveld KAF, Höll C, Janofske D, Karwath B, Kerntopf B, Rühlemann C, Willems H (1999) Calcareous Dinoflagellate Cysts as Paleo-environmental Tools. In Fischer G, Wefer G, (eds) Use of Proxies in Paleoceanography: Examples from the South Atlantic. Springer, Berlin, pp 145-164 


\section{Figure legends}

Figure 1. Light micrographs of the monadoid stage of Ensiculifera mexicana strain LMBE-TY1 from Korea. (A) Surface focus of ventral view showing the sulcus and cingulum. (B) Deeper focus of ventral view showing the outline shape and a pyrenoid (Pr). (C) Surface focus of left lateral view. (D) Deeper focus of left lateral view showing the position of the nucleus (n). (E) Surface focus of dorsal view showing the cingulum. (F) Deeper focus of dorsal view showing the position of the nucleus (n). (G) Epifluorescence image of a cell in ventral view showing the chlorophyll autofluorescence and peripheral chloroplast network. $(\mathbf{H})$ Dorsal view of a SYTOX green-stained cell showing the shape of the nucleus. (I) Right lateral view of a SYTOX green-stained cell showing the position of the nucleus. Scale bars: A-I $=10 \mu \mathrm{m}$.

Figure 2. Scanning electron micrographs of the monadoid stage of Ensiculifera mexicana strain LMBE-TY1 from Korea. (A) Ventral view. (B) Left lateral view. (C) Dorsal view. (D) Ventralright lateral view. (E) Apical view, showing apical pore (Po), x plate and epithecal plate pattern. (F) Thecal inside view of hypotheca. (G) Antapical view, showing hypothecal plate pattern. (H) Detail of the Sa and c1 plates showing a long spine attached to the cl plate. (I) Thecal inside view of sulcal plates. Scale bars: $A-G=10 \mu \mathrm{m} ; \mathrm{H}, \mathrm{I}=1 \mu \mathrm{m}$.

Figure 3. Light and scanning electron micrographs of the coccoid stage of Ensiculifera mexicana from Korea. (A) Apical view of a living coccoid cell with a pentagonal apical shape and a large red pigment body (arrow). (B) Surface focus of lateral view showing a subrectangular shape and a large red pigment body (arrow). (C) Scanning electron micrograph of a coccoid cell showing a calcareous wall. (D) Deeper focus of a living coccoid cell showing a subspherical endocoel. (E) 
Surface focus of living coccoid cells in lateral view. (F) Apical view of an empty coccoid cell showing a subcircular archeopyle. (G-I) Scanning electron micrographs of empty coccoid cells showing an attached operculum. Scale bars: A-I $=10 \mu \mathrm{m}$.

Figure 4. Light and scanning electron micrographs of the coccoid stage of Ensiculifera carinata isolated from Korea (A, B, E, F) and New Zealand (C, D). (A) Light micrograph of a living coccoid cell. (B-C) Scanning electron micrographs of coccoid cells showing a ridged calcareous wall, parasulcus (arrowhead) and paracingulum (arrow). (D) Detail of cell surface showing numerous needle-shaped calcareous crystals. (E) A naked coccoid cell showing a large red pigment body (arrow). (F) Empty coccoid cell showing a theropylic archeopyle. The same cell as in Figure 4E. Scale bars: A-C, E, $F=10 \mu \mathrm{m} ; \mathrm{D}=1 \mu \mathrm{m}$.

Figure 5. Scanning electron micrographs of the monadoid stage of Pentapharsodinium imariense comb. nov., strain OP2E4, established from a coccoid cell from Opua Bay, New Zealand. (A) Ventral view. (B) Dorsal view. (C) Apical view, showing the apical pore (Po), $\mathrm{x}$ plate and epithecal plate pattern. (D) Ventral view of hypotheca, showing a long spine attached to the c1 plate. (E) Thecal inside view of sulcal plates. (F) Antapical view, showing the hypothecal plate pattern. Scale bars: $\mathrm{A}, \mathrm{B}=10 \mu \mathrm{m} ; \mathrm{C}-\mathrm{F}=5 \mu \mathrm{m}$.

Figure 6. Light and scanning electron micrographs of the coccoid stage of Pentapharsodinium imariense comb. nov. from Opua Bay, New Zealand. (A-D) Light micrographs of living coccoid cells. (E-F) Scanning electron micrographs of coccoid cells. (D) Detail of the cell surface showing the distal end of the processes, ranging from simple to branched at the apex, with or without 
capitate tips. Scale bars: A-F $=10 \mu \mathrm{m} ; \mathrm{G}-\mathrm{H}=1 \mu \mathrm{m}$.

Figure 7. Light and scanning electron micrographs of the monadoid and coccoid stages of Matsuokaea loeblichii comb. nov. strain LMBE-JH2 from Korea. (A) Ventral view of monadoid cell, focus in the cell middle plane, showing a red eyespot (arrow). (B) Ventral view of monadoid cell, focus in the cell surface. (C) Dorsal view of monadoid cell, focus in the cell surface, showing the cingulum (arrows). (D) Dorsal view of monadoid cell, focus in the cell middle plane, showing the position of the nucleus (n). (E) Dorsal view view of a SYTOX green-stained cell showing the shape of the nucleus. (F) Epifluorescence image of a cell in ventral view showing the chlorophyll autofluorescence and peripheral chloroplast network. (G, H) Light micrographs of living coccoid cells, showing a large red pigment body (arrows). (I) Scanning electron micrograph of a coccoid cell showing a smooth organic wall without any ornamentation. Scale bars: A-I $=10 \mu \mathrm{m}$.

Figure 8. Scanning electron micrographs of monadoid cells of Matsuokaea loeblichii comb. nov., strain LMBE-JH2 from Korea. (A) Ventral view. (B) Ventral-left lateral view. (C-D) Dorsal view. (E) Ventral-right lateral view. (F) Apical view, showing epithecal plate pattern. (G) Detail of the apical pore plate $(\mathrm{Po}), \mathrm{x}$ plate and the first apical plate. (H) Antapical view, showing hypothecal plate pattern. (I) Ventral-left lateral view of hypotheca, showing the cingular plates. (J) Details of the sulcal plates. Scale bars: A-I $=5 \mu \mathrm{m}$.

Figure 9. Schematic drawings of thecal plate patterns of Ensiculifera mexicana, Pentapharsodinium imariense comb. nov. and Matsuokaea loeblichii comb. nov. Arrowheads indicate the plate overlap pattern. Abbreviations: $n^{\prime}$ : apical plate. $n^{\prime \prime}$ : precingular plate. $n^{\prime \prime \prime}$ : 
postcingular plate. $\mathrm{n}^{\prime \prime \prime \prime}:$ antapical plate. na: anterior intercalary plate. $\mathrm{nC}$ : cingular plate. Sa: anterior sulcal plate. Sd: right sulcal plate. Sp: posterior sulcal plate. Ss: left sulcal plate. Po: apical pore plate. $x$ : canal plate.

Figure 10. Maximum likelihood (ML) tree showing the phylogenetic position of Ensiculiferaceae (E/Pe; shaded in grey) based on SSU-ITS1-5.8S-ITS2-LSU concatenated sequences (3,767bp). The sequences of Amphidomataceae and Heterocapsaceae species were used as the outgroup. The numbers on each node are the bootstrap values (\%) followed by the Bayesian posterior probability (PP). Only bootstrap values above $50 \%$ and with a PP above 0.7 are shown. See Table S1 for the full list of accessions used. The circular diagrams represent the number of cingular plates. Abbreviations: E/Pe: clade including Ensiculifera and Pentapharsodinium. PER: Peridiniaceae. POP: Peridiniopsidaceae. T/Pf: clade including Pfiesteria and Thoracosphaera. dt: clade including Durinskia and Unruhdinium. Scale bar $=0.05$ nucleotide substitutions per site.

Figure 11. Maximum likelihood (ML) tree showing the phylogenetic positions of Ensiculifera, Pentapharsodinium and Matsuokaea gen. nov. based on ITS1+5.8S+ITS2 sequences (1,114 bp). Names in bold represent sequences obtained in this study. The 49 sequences of other Thoracosphaeraceae, Kryptoperidiniaceae, Amphidomataceae and Heterocapsaceae species were used as the outgroup. The numbers on each node are the bootstrap values (\%) followed by the Bayesian posterior probability (PP). Only bootstrap values above $50 \%$ and with a PP above 0.7 are shown. See Supplementary Material Table S1 for a full list of the accessions used. The GenBank accession number follows the taxon name. From top to bottom on the right, Ensiculifera mexicana has a calcareous coccoid stage; the coccoid stage of Pentapharsodinium imariense comb. nov. has 
an organic wall bearing capitate processes; the coccoid stage of Matsuokaea loeblichii comb. nov. has a smooth organic wall without any ornamentation. Scale bar $=0.10$ nucleotide substitutions per site. 


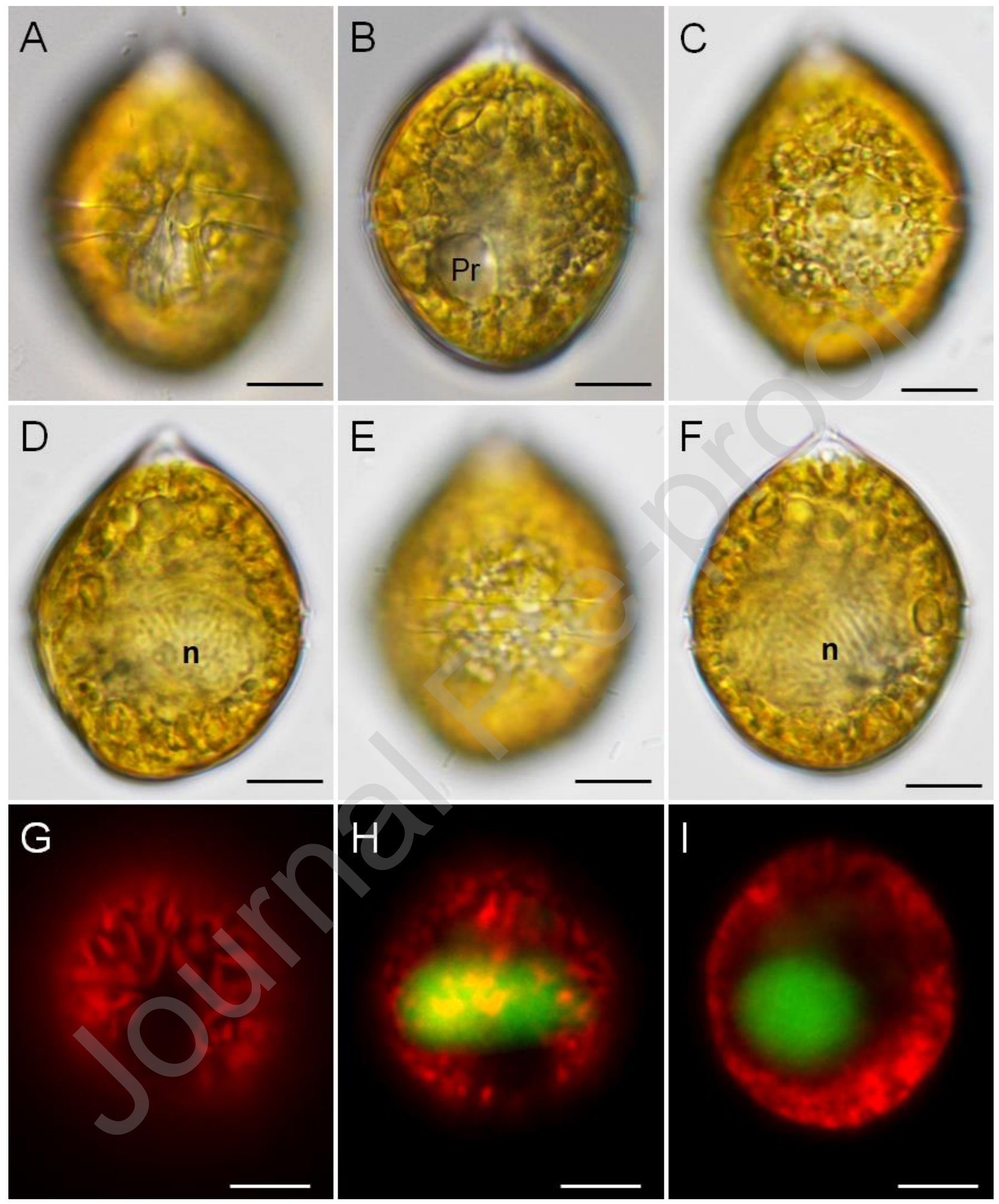

Fig.1 


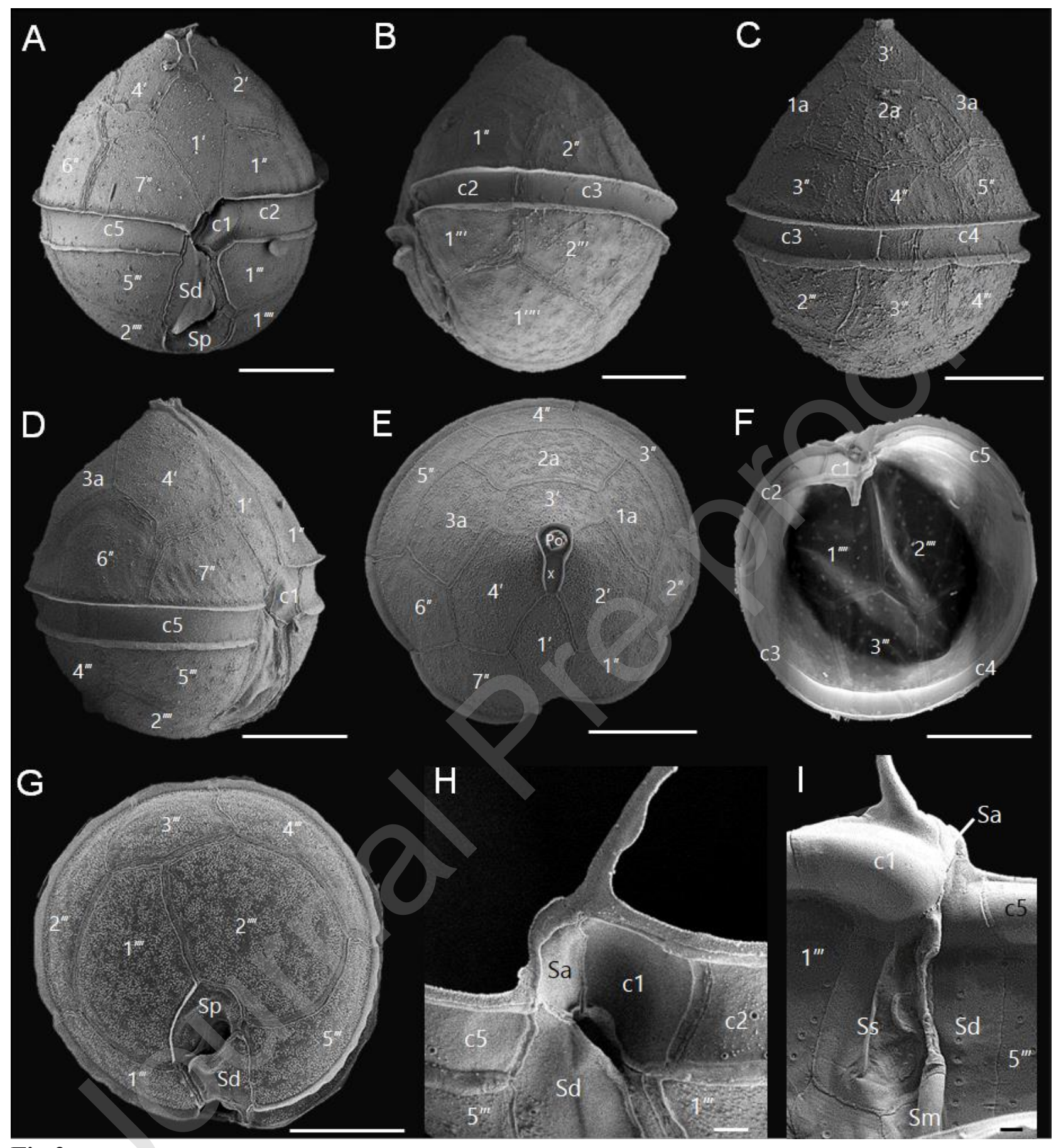

Fig.2 


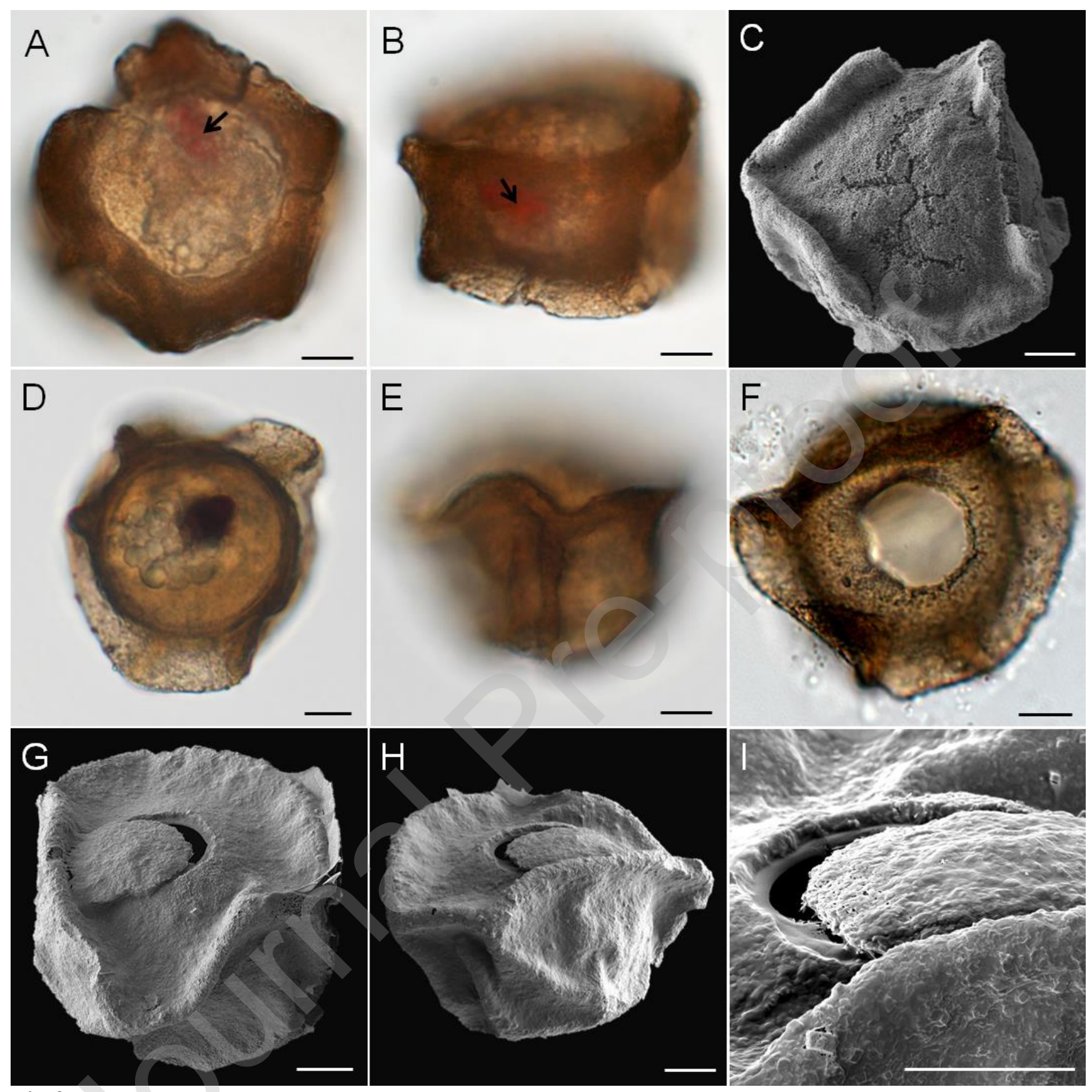

Fig.3 

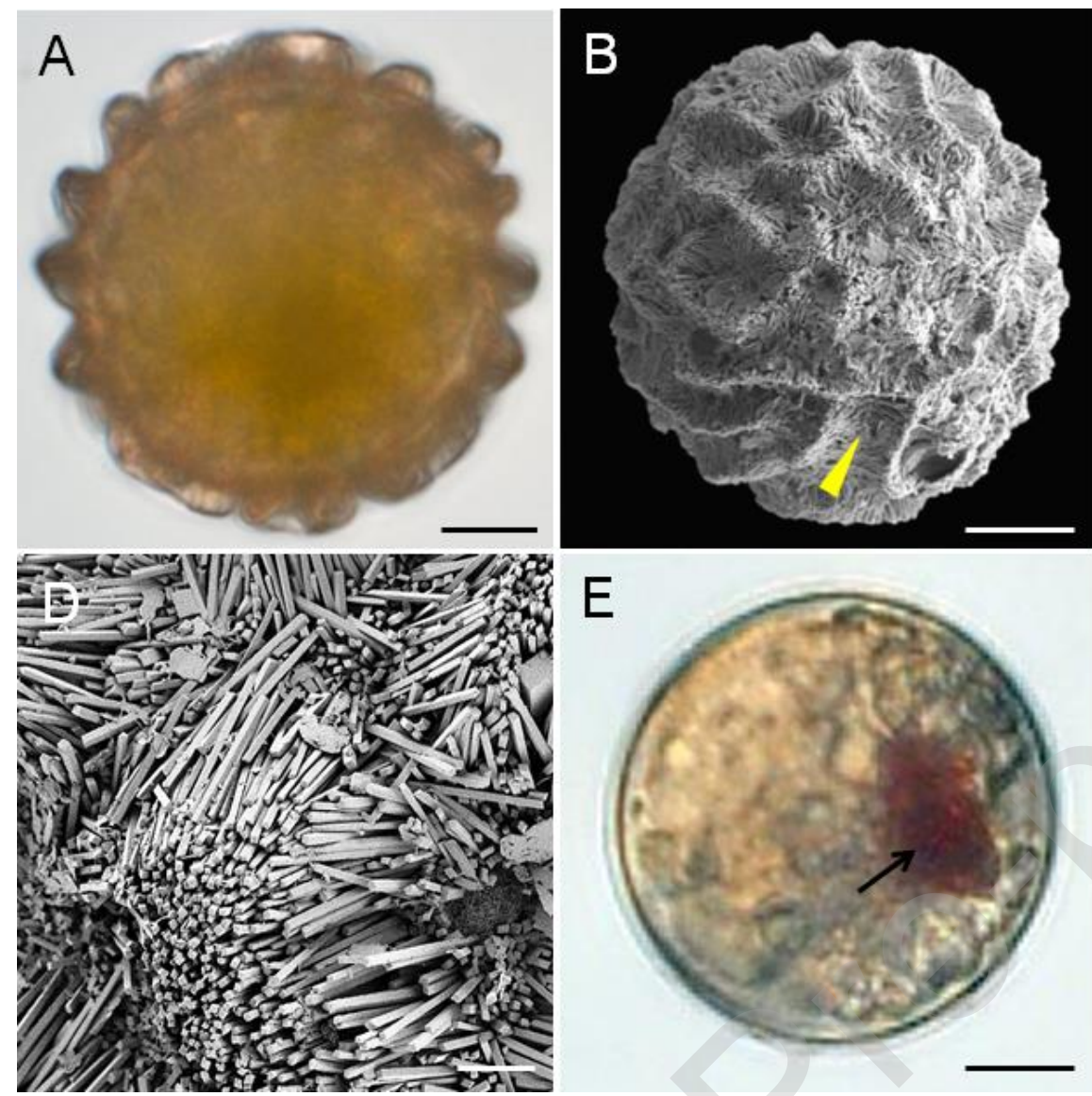

Fig.4
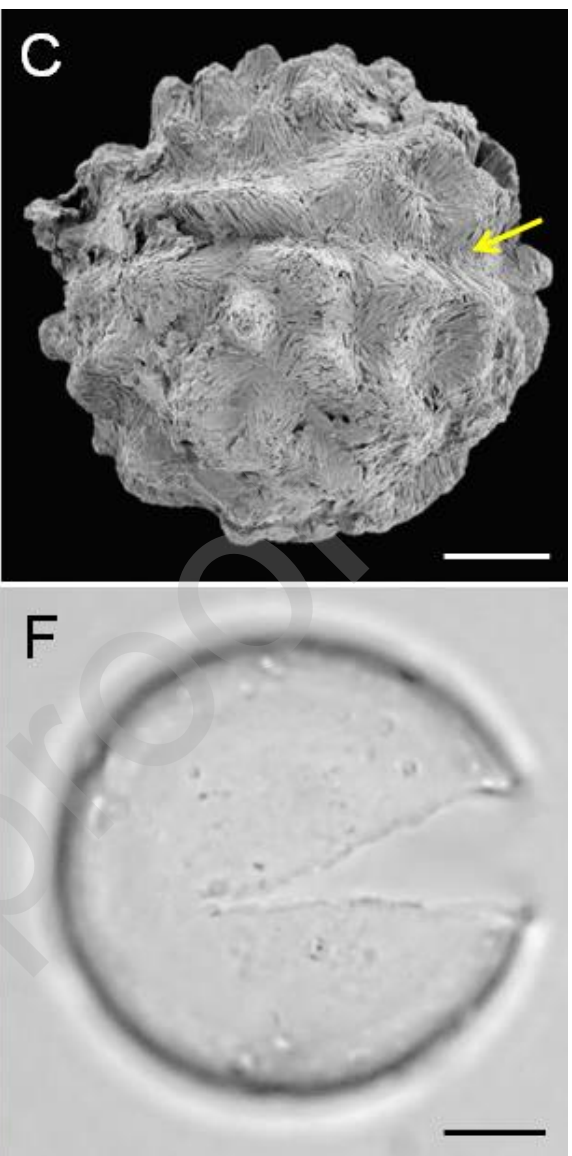


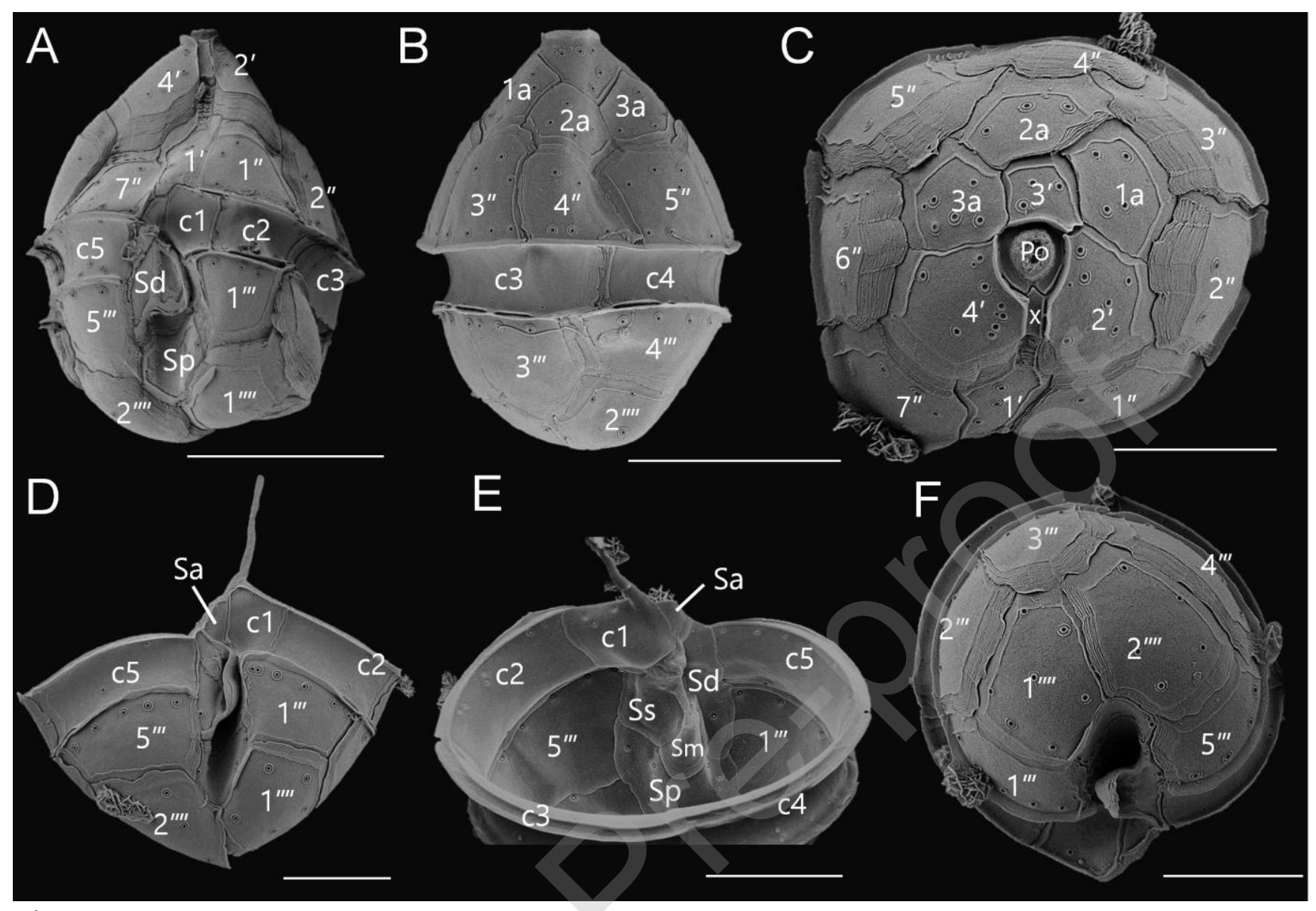

Fig.5 

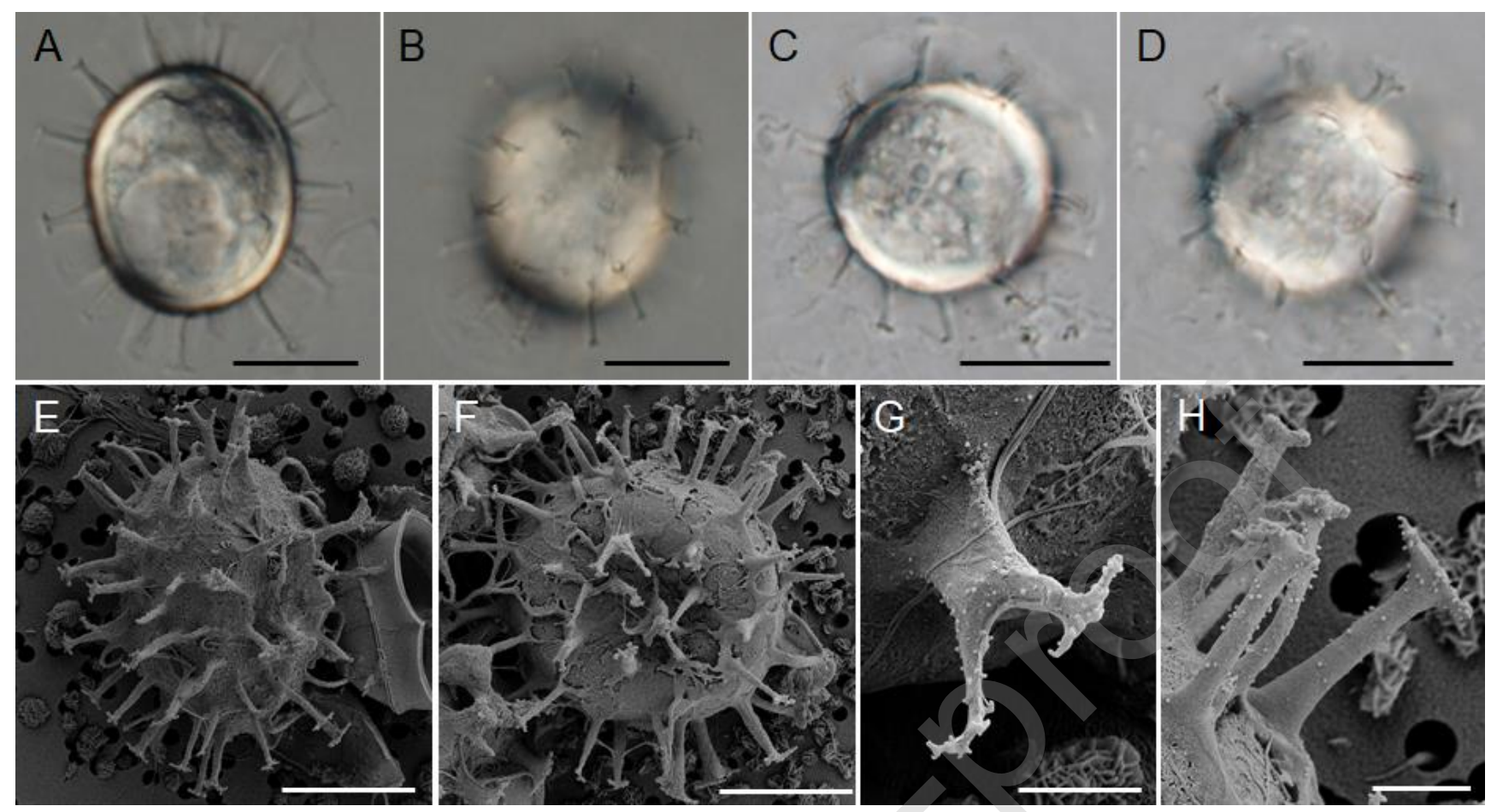

Fig.6 

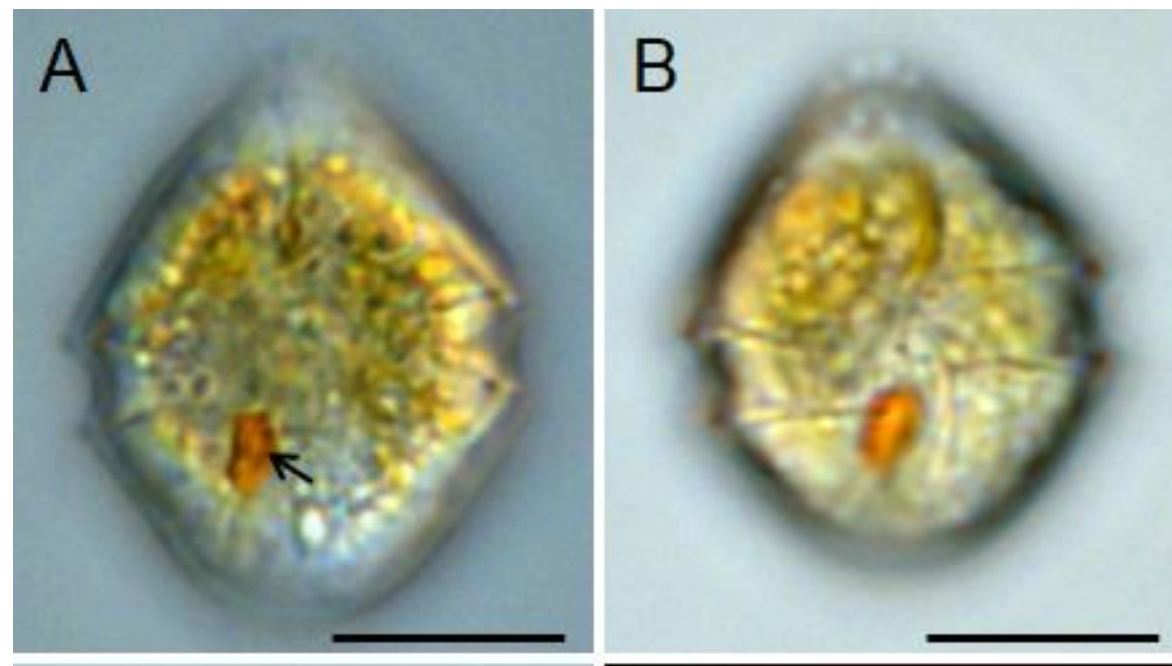

C
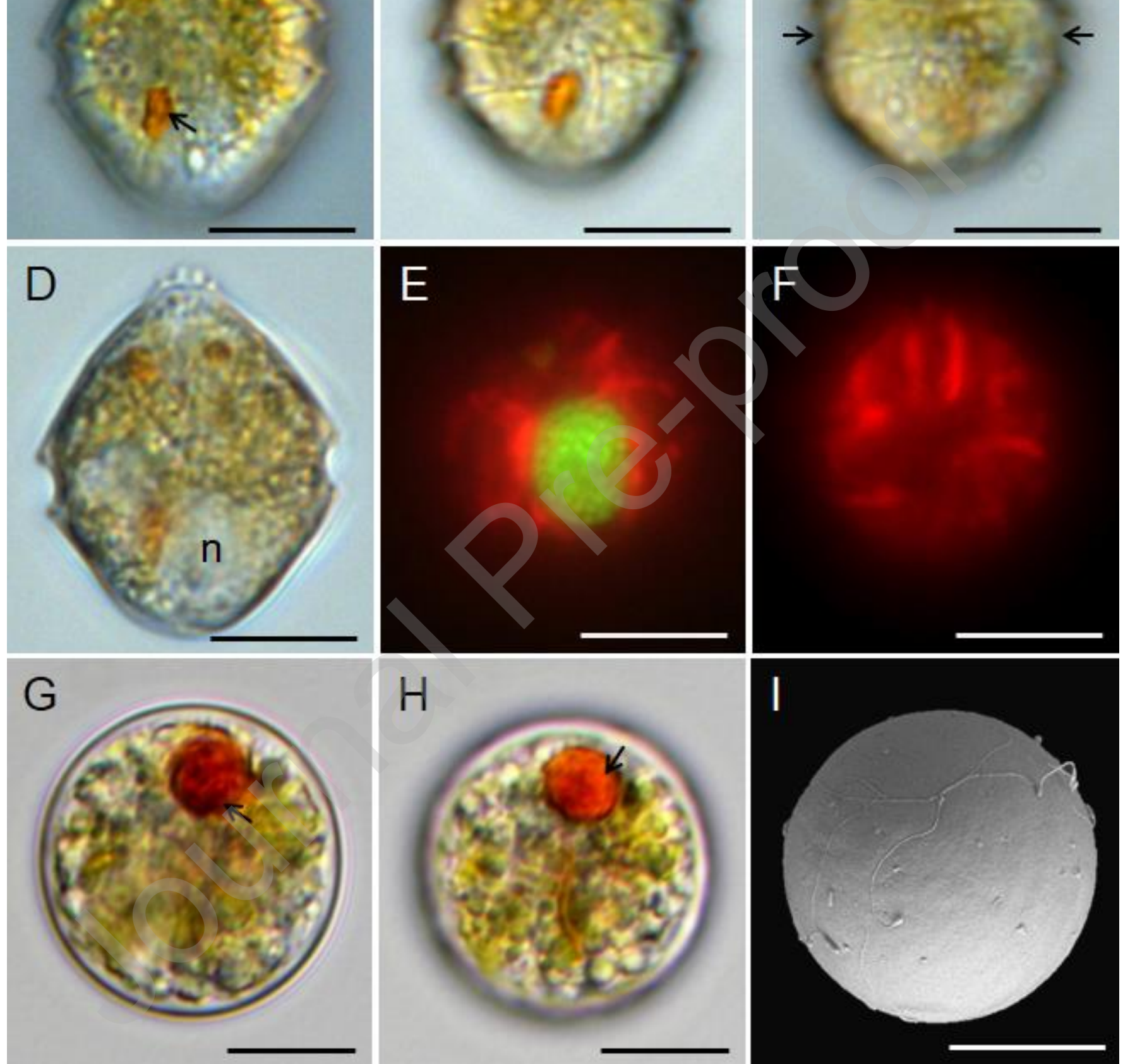

Fig.7 


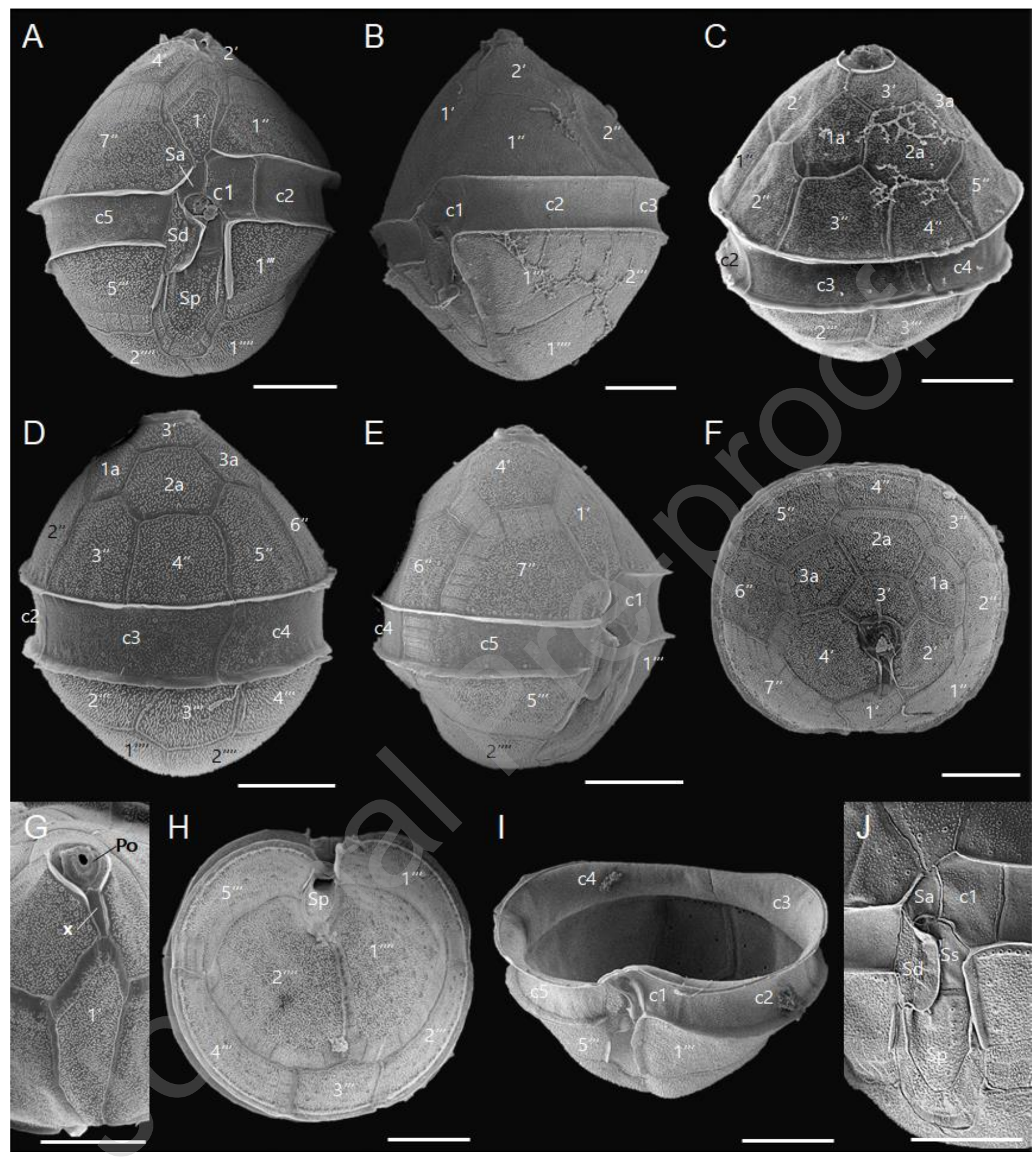

Fig.8 


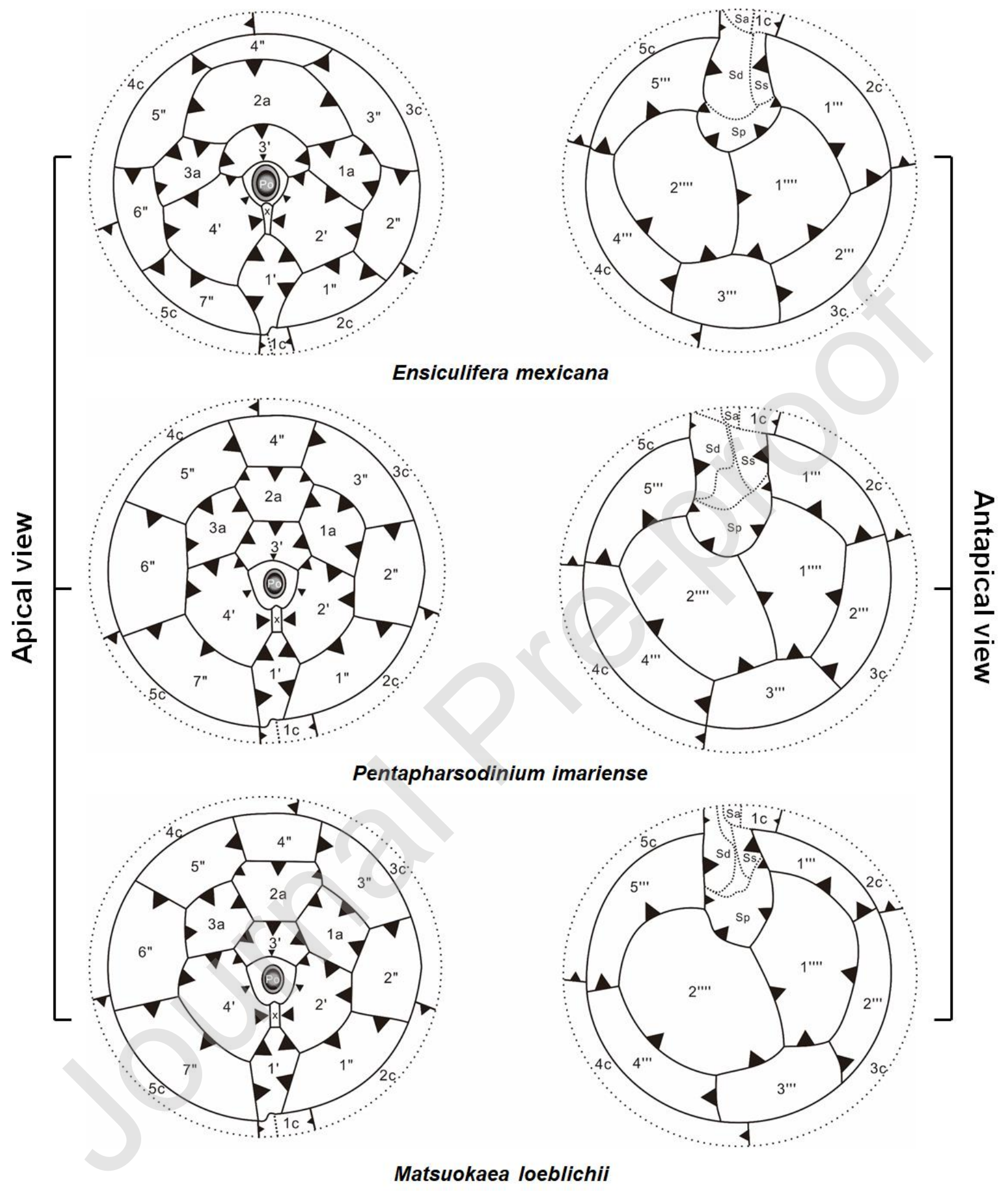

Fig. 9 


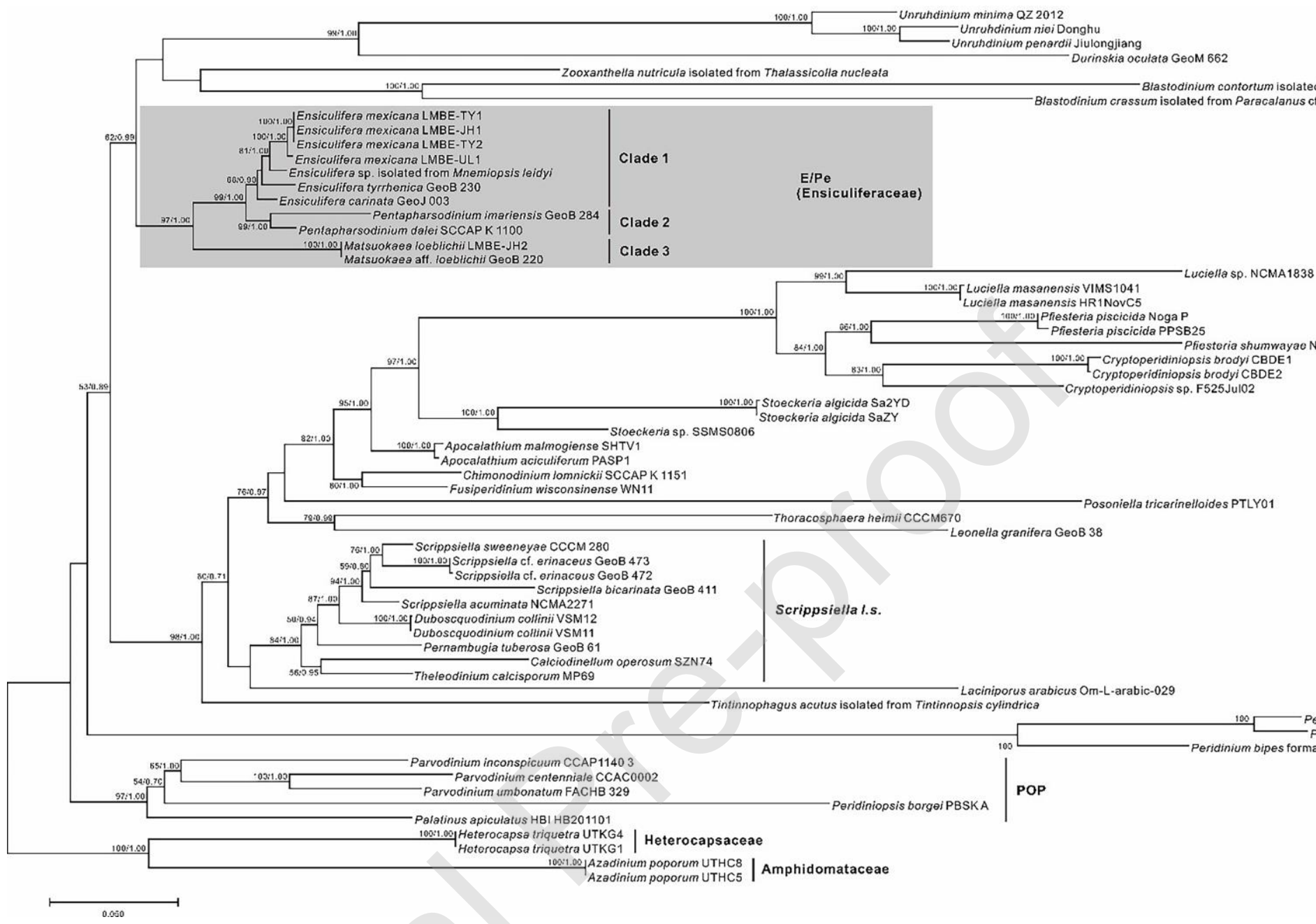

Fig. 10 


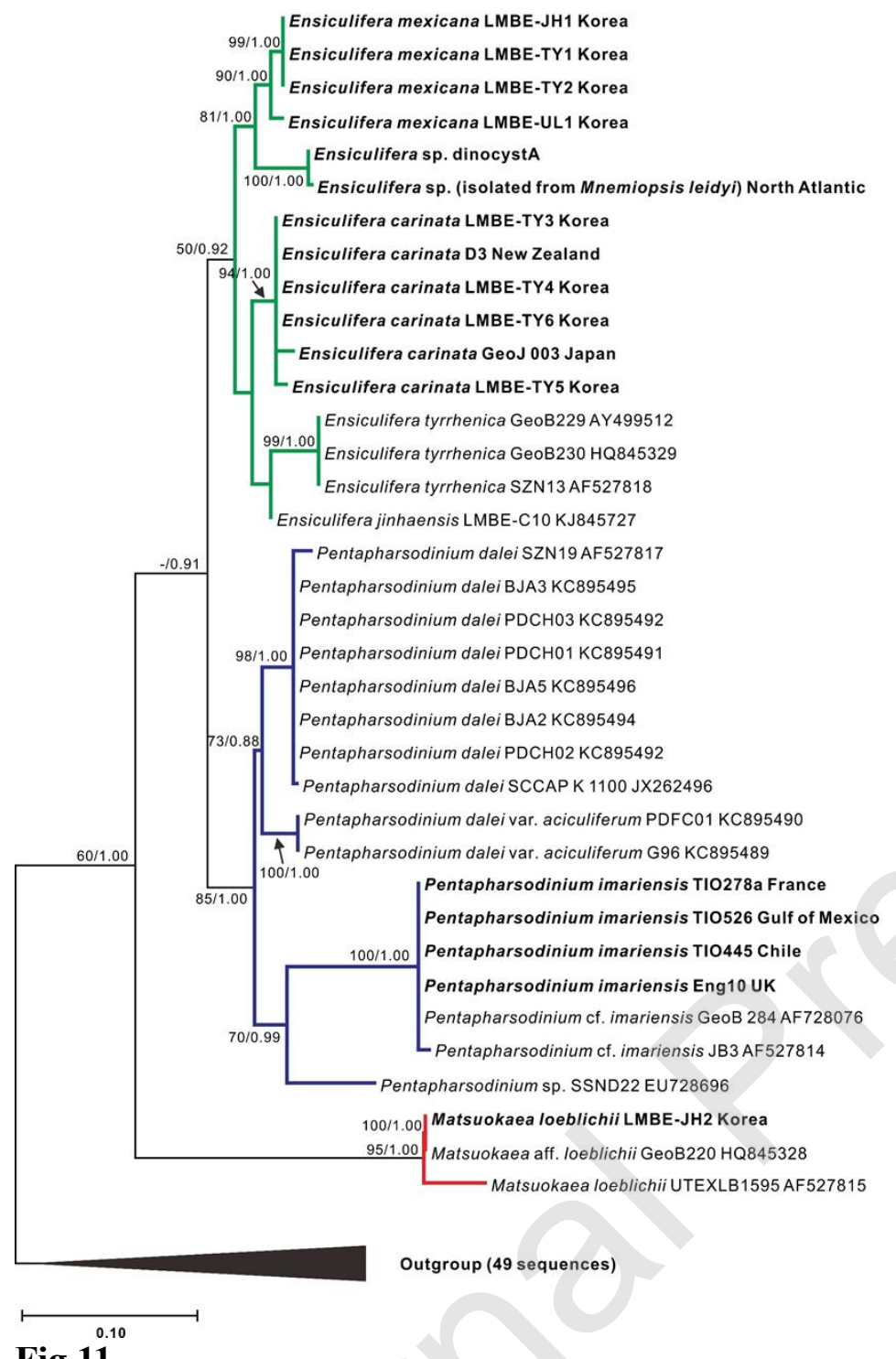

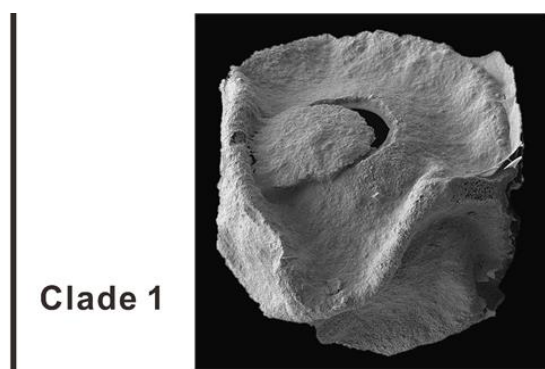

Calcareous coccoid cell

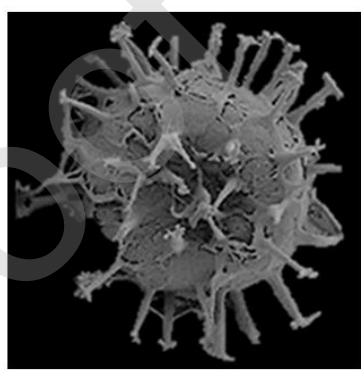

Clade 2 Organic-walled coccoid cell with capitate processes

Clade 3

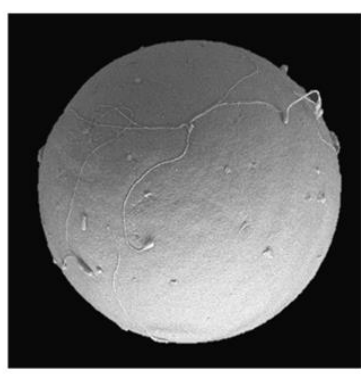

Smooth and organic-walled coccoid cell

Fig.11 
Table 1. Morphological comparison of species, which constitute the Ensiculiferaceae, fam. nov., and of which sequence data are available.

\begin{tabular}{|c|c|c|c|c|c|c|c|c|c|c|c|c|c|}
\hline \multirow[b]{2}{*}{ Species } & \multirow[b]{2}{*}{ Habitat } & \multicolumn{5}{|c|}{ Coccoid stage } & \multicolumn{6}{|c|}{ Monadoid stage } & \multirow[b]{2}{*}{ Reference } \\
\hline & & $\begin{array}{l}\text { Cell } \\
\text { wall }\end{array}$ & $\begin{array}{c}\text { Surface } \\
\text { ornamentations }\end{array}$ & Shape & $\begin{array}{l}\text { Archeopyl } \\
\text { e }\end{array}$ & Size $(\mu \mathrm{m})$ & $\begin{array}{c}\text { Number of } \\
\text { cingular } \\
\text { plates }\end{array}$ & $\begin{array}{l}\text { A spine } \\
\text { attached to } \\
\text { c1 or Sa }\end{array}$ & $\begin{array}{c}\text { A projection } \\
\text { at the } \\
\text { hypotheca }\end{array}$ & $\begin{array}{c}\text { Surface } \\
\text { ornamentations }\end{array}$ & $\begin{array}{l}\text { Nucleus } \\
\text { position }\end{array}$ & Size $(\mu \mathrm{m})$ & \\
\hline \multirow{2}{*}{ Ensiculifera carinata } & & $\mathrm{C}$ & $\begin{array}{l}\text { significantly } \\
\text { wrinkled }\end{array}$ & spherical & $\begin{array}{l}\text { therophylic } \\
\text { intercalary }\end{array}$ & $\begin{array}{l}41.6-58.5 \\
\text { D }\end{array}$ & 5 & + & + & $\begin{array}{l}\text { pores and small } \\
\text { bumps }\end{array}$ & - & $\begin{array}{l}20.5-51.2 \mathrm{~L} \\
16.8-36.5 \mathrm{~W}\end{array}$ & This study \\
\hline & & $\mathrm{C}$ & $\begin{array}{l}\text { significantly } \\
\text { wrinkled }\end{array}$ & spherical & $\begin{array}{l}\text { therophylic } \\
\text { intercalary }\end{array}$ & $43-54 \mathrm{D}$ & 5 & + & + & small pores & - & $\begin{array}{l}18.3-54.2 \mathrm{~L} \\
16.2-38.2 \mathrm{~W}\end{array}$ & Matsuoka et al. (1990) \\
\hline $\begin{array}{l}\text { Ensiculifera jinhaensis, } \\
\text { comb. nov. }\end{array}$ & $\underset{\mathrm{e}}{\operatorname{marin}}$ & $\mathrm{C}$ & smooth & spherical & $\begin{array}{l}\text { theropylic } \\
\text { intercalary }\end{array}$ & $25-38 \mathrm{D}$ & 5 & + & + & pores and spines & hypotheca & $\begin{array}{l}29-40 \mathrm{~L}, \\
24-35 \mathrm{~W}\end{array}$ & Li et al. (2015) \\
\hline \multirow[t]{2}{*}{ Ensiculifera mexicana } & $\underset{\mathrm{e}}{\operatorname{marin}}$ & $\mathrm{C}$ & smooth & $\begin{array}{l}\text { oblate-type, } \\
\text { pentagonal in } \\
\text { apical view } \\
\text { and } \\
\text { subrectangula } \\
\text { r in lateral } \\
\text { view }\end{array}$ & $\begin{array}{l}\text { subcircular } \\
\text { apical }\end{array}$ & $\begin{array}{l}57.5-68.4 \\
\text { L, } \\
48.5-58.7 \\
\text { W }\end{array}$ & 5 & + & - & $\begin{array}{l}\text { pores and small } \\
\text { bumps }\end{array}$ & central part & $\begin{array}{l}30.7-49.6 \mathrm{~L} \\
25.5-38.9 \mathrm{~W}\end{array}$ & $\begin{array}{l}\text { This study; Wall and } \\
\text { Dale, 1968: pl. CLXXI 20; } \\
\text { Wall et al., 1970; Keupp, } \\
\text { 1991 }\end{array}$ \\
\hline & & - & - & & - & - & 5 & + & - & - & - & $\begin{array}{l}42-45 \mathrm{~L} \\
34-36 \mathrm{~W}\end{array}$ & Balech (1967) \\
\hline $\begin{array}{l}\text { Ensiculifera tyrrhenica, } \\
\text { comb. nov. } \\
{[=+ \text { Calcicarpinum }} \\
\text { bivalvum }]\end{array}$ & $\underset{\mathrm{e}}{\operatorname{marin}}$ & $\mathrm{C}$ & smooth & Napoleon hat & $\begin{array}{l}\text { circular } \\
\text { apical }\end{array}$ & $25-32 \mathrm{D}$ & 5 & - & - & pores and knobs & central part & $\begin{array}{l}19-26 \mathrm{~L} \\
15-22 \mathrm{~W}\end{array}$ & Montresor et al. (1993) \\
\hline \multirow{2}{*}{$\begin{array}{l}\text { Matsuokaea loeblichii, } \\
\text { comb. nov. }\end{array}$} & $\underset{\mathrm{e}}{\operatorname{marin}}$ & o & smooth & spherical & - & $\begin{array}{c}19.5-25.2 \\
\mathrm{D}\end{array}$ & 5 & - & - & $\begin{array}{l}\text { pores and small } \\
\text { bumps }\end{array}$ & hypotheca & $\begin{array}{l}18.6-31.3 \mathrm{~L}, \\
14.6-22.5 \mathrm{~W}\end{array}$ & This study \\
\hline & & & & - & - & - & 5 & - & - & $\begin{array}{l}\text { pores and small } \\
\text { granules }\end{array}$ & central part & $\begin{array}{l}20-30 \mathrm{~L}, \\
15-25 \mathrm{~W}\end{array}$ & $\begin{array}{l}\text { Cox and Arnott (1971), } \\
\text { D'Onofrio et al. (1999) }\end{array}$ \\
\hline Pentapharsodinium dalei & $\underset{\mathrm{e}}{\operatorname{marin}}$ & $\mathrm{o}$ & $\begin{array}{l}\text { capitate } \\
\text { processes }\end{array}$ & spherical & splitting & $24-38 \mathrm{D}$ & 5 & - & - & $\begin{array}{l}\text { smooth, pores } \\
\text { surrounded by 2-3 } \\
\text { concentric ridges }\end{array}$ & central part & $\begin{array}{l}\text { 10-21 L, } \\
8-19 \mathrm{~W}\end{array}$ & $\begin{array}{l}\text { Lewis (1991), Gu et al. } \\
\text { (2013b) }\end{array}$ \\
\hline $\begin{array}{l}\text { Pentapharsodinium dalei } \\
\text { var. aciculiferum }\end{array}$ & $\underset{\mathrm{e}}{\operatorname{marin}}$ & o & $\begin{array}{l}\text { capitate } \\
\text { processes }\end{array}$ & spherical & - & $17-20.8 \mathrm{D}$ & 5 & + & - & $\begin{array}{l}\text { smooth, pores } \\
\text { surrounded by } 1-2 \\
\text { concentric ridges }\end{array}$ & central part & $\begin{array}{l}14.5-20.0 \mathrm{~L}, \\
10.8-16.8 \mathrm{~W}\end{array}$ & Gu et al. (2013b) \\
\hline \multirow{2}{*}{$\begin{array}{l}\text { Pentapharsodinium } \\
\text { imariense, comb. nov. }\end{array}$} & marin & $\mathrm{o}$ & $\begin{array}{l}\text { capitate } \\
\text { processes }\end{array}$ & spherical & - & $\begin{array}{c}19.6-23.5 \\
\mathrm{D}\end{array}$ & 5 & + & - & $\begin{array}{l}\text { smooth, pores } \\
\text { surrounded by } 1-2 \\
\text { concentric ridges }\end{array}$ & - & $\begin{array}{l}\text { 18.1-21.3L, } \\
13.2-17.5 \mathrm{~W}\end{array}$ & This study \\
\hline & $\mathrm{e}$ & $\mathrm{o}$ & $\begin{array}{l}\text { capitate } \\
\text { processes }\end{array}$ & spherical & - & 23-29 D & 5 & + & - & $\begin{array}{l}\text { smooth, small } \\
\text { pores }\end{array}$ & central part & $\begin{array}{l}17-25 \mathrm{~L}, \\
14-21 \mathrm{~W}\end{array}$ & $\begin{array}{l}\text { Kobayashi and Matsuoka } \\
\text { (1995) }\end{array}$ \\
\hline
\end{tabular}

Abbreviations used: $\mathrm{C}=$ calcareous, $\mathrm{O}=$ organic-walled, $+=$ observed, - = not observed, $\mathrm{D}=$ diameter, $\mathrm{L}=\mathrm{long}, \mathrm{W}=$ wide. 